\title{
Accounting Analyses of Momentum and Contrarian Strategies in Emerging Markets
}

\author{
Matthias Nnadi \\ School of Management, \\ Cranfield University, UK \\ Email: Matthias.nnadi@cranfield.ac.uk
}

\author{
Sailesh Tanna \\ School of Economics, Finance and Accounting, \\ Coventry University, UK \\ Email: $\underline{\text { s.tanna@ } @ \text { coventry.ac.uk }}$
}

\begin{abstract}
We analyse the momentum and contrarian effects of stock markets in Brazil, Russia, India, China and South Africa (BRICS) using accounting data. The five markets show different characteristics with the Indian market having the strongest momentum effect. Stock markets in China and Brazil show significant short-term contrarian profit and intermediate to longterm momentum profit while South Africa shows short-term momentum effect and intermediate to long-term contrarian effect. The Russian stock market reveals largely insignificant momentum portfolio returns. We also find evidence that the contrarian profits in South Africa and China are caused by relatively high loser returns while positive momentum profit in India results from relatively high winner returns.
\end{abstract}

Keywords: Portfolio; contrarian; momentum; markets, emerging; strategies 


\section{Introduction}

Empirical evidence shows that short and long-term reversal effects, as well as medium to long-term momentum effects, appear not only in the U.S. stock markets but also in other developed countries (Schiereck et al, 1999). However, studies for the emerging markets are scarce. Furthermore, prior studies have yielded mixed results. For instance, Chang et al, (1995) document that abnormal returns can be achieved by applying contrarian strategy in the Japanese and Korean markets. Hameed and Ting (2000) find a positive statistical reversal effect in the Malaysian market which supports the market overreaction hypothesis. Nevertheless, Hameed and Kusnadi (2002) and Griffin et al (2005) find no momentum effect in the Asia and Pacific region (Taiwan, Singapore, Korea, Hong Kong, Malaysia and Thailand).

Most momentum studies in emerging economies have focused on the existence and formation mechanism of momentum profits (Okunev and White 2003; Marshall and Cahan, 2005), and have used short holding periods (Hon and Tonks, 2001; Forner and Marhuenda, 2003). The narrow focus and short window in these studies leave some gap in their findings.

This study has three main objectives: (1) Examine the existing literature on momentum strategy particularly in emerging markets; (2) Based on Jegadeesh and Titman (1993) methodology, investigate if momentum or reversal effect arises in emerging markets, especially in Brazil, Russia, India, China and South Africa (BRICS), and identify the characteristics of momentum or contrarian profits in these countries. These five countries are considered to be fastest growing economies in the world and are projected to be wealthier than most of the developed economies by 2050 (World Bank, 2006); (3) Compare and contrast the results with the previous findings and explore the sources of momentum or contrarian profits in the BRICS economies.

Our study contributes to the existing literature on momentum and contrarian strategies in the following ways: (1) In contrast with previous studies, longer holding periods are considered. Previous research (Jegadeesh and Titman, 1993; Conrad and Kaul, 1998, and Liu, Strong and $\mathrm{Xu}, 2003$ ) has tended to consider a special time slot, for example, quarterly basis which inadvertently does not fully capture the elasticity of momentum and contrarian strategies. We extend the holding period to a monthly basis from month 1 to 12 thereby allowing the trend of momentum or contrarian profit to be observed with the increasing holding period. In addition, we use a longer time span (January 2003 to December 2013) and an enlarged 
sample size. (2) Our study focuses on the BRICS economies which, taken together, play a significant role in the global financial industry and have more comprehensive stock exchanges compared to other emerging markets, such as Mexico, Indonesia and Turkey. To the best of our knowledge, our study is the first to simultaneously compare the contrarian and momentum effects for the BRICS markets. While some studies, such as Claire and Thomas (1995); Jostova et al (2013) and Chen et al (2015), have focussed on specific markets, empirical research on these five markets is limited.

The remainder of this paper is organised as follows: Section 2 introduces the theoretical background including discussion of relevant evidence and some common stock market anomalies in light of the contrarian and momentum literature. Section 3 provides discussion of data sources, methodology and hypotheses which characterise the measures of stock return and set up portfolios. Section 4 presents the empirical results for each of the emerging markets with discussion of the potential sources of momentum and contrarian profit. This breaks down into three parts: (1) winner portfolio's performance; (2) loser portfolio's performance; and (3) momentum strategy performance. Section 5 is the conclusion and recommendations.

\section{Theoretical background and literature}

An increasing number of empirical studies prove that future stock price movements are predictable from past stock return patterns, and investors may decide on future trading strategies based on momentum or reversal according to the stocks' past performance. The current study is premised on the Random Walk Hypothesis and the Prospect Theory.

The Random Walk Hypothesis argues that stock market prices evolve according to a random process and therefore cannot be predicted. This theory is supported by the efficient-market hypothesis (Fama, 1970).

The Prospect Theory argues that people make decisions based on the potential value of losses and gains rather than the final outcome, and that people evaluate these losses and gains using certain benchmarks (Kahneman and Tversky, 1979). The theory describes the decision processes in two stages: editing and evaluation. During editing, outcomes of a decision are based on set of efficient rules. People decide which outcomes they consider satisfactory; set a benchmark, and then consider lesser outcomes as losses and greater ones as gains. The 
editing phase aims to alleviate any cognitive bias (Tversky and Kahneman, 1986; 1992). During the evaluation stage, individuals tend to derive satisfaction based on the potential outcomes and their respective probabilities, and then choose the alternative having a higher satisfaction. As noted by Ouzounis et al (2009), portfolios can generate different results depending on the method applied.

We argue that no momentum profit can be acquired where future prices cannot be predicted from analysing past events as they follow the Random Walk Hypothesis. In fact, there is evidence to suggest that under reaction to earnings announcement can trigger momentum in the short run while delay by analysts in responding to good news creates opportunity for contrarians to earn abnormal returns (Wu and Lin, 2013). Consequently, winner-loser portfolios will generate zero profit, as investors are more risk-averse towards earnings but more risk-seeking towards losses. Thus, our argument is further supported by the Prospect theory which posits that investors close their positions when they earn a little profit but will not quit when they are making losses. Investors keep the losers and sell the winners. Our study demonstrates that all relevant information is always incorporated and reflected on stock prices, such that arbitrage is minimised. Yet, some studies show that mean-reversion and overreaction can generate the momentum effect (Kang et al, 2002; Biglova et al, 2004).

Chui, Titman and Wei (2010) and Hameed and Kusnadi (2002) were the first to analyse the profitability of momentum strategies in eight and six Asian countries (Hong Kong, Indonesia, Japan, Korea, Malaysia, Singapore, Taiwan and Thailand), respectively, from 1975 to 2000. They find weak and insignificant momentum effects in Japan; in particular, it was not valid in either Korea or Indonesia. In order to compare the magnitude of the momentum effect, Griffin et al (2005) examine countries from Africa, America, Asia and Europe and report that Asian countries exhibit the lowest momentum effect.

Studies by Cheng and Wu (2010) and Habib and Hasan (2012) on Hong Kong stock market and Karachi Stock Exchange of Pakistan, respectively, indicate that momentum effect is low and insignificant for Asian countries. This could be explained by the differences between the Western and Asian countries in terms of exchange, culture and institutions (Nnadi, 2015). Although there is only very low momentum effect in both researches, they show positive profitability of momentum strategies. The results are consistent with Hameed and Ting (2002) and Griffin et al (2005). 


\section{Stock Market Anomalies}

Book-to-market: This can be a good measure of predicting future stock returns. Fama and French three-factor model (1993) considers book-to-market (apart from leverage, size and earnings/price and average stock returns) to establish existence of a positive relationship between beta and stock returns. Our study finds further evidence that size and book-to-market have a significant effect on stock returns.

Size: Some previous studies have shown that large firms experience lower risk-adjusted returns than small firms (Banz and Reinganum, 1981; Roll, 1981; Edmister and James, 1983) Similarly, Chen (2003) confirms that portfolio formed by size, book-to-market and dividend yield can be used to decide investment strategies and there is certainly a profit margin in choosing stocks with in-favour or out-of-favour characteristic. We argue that small firms with more frequent trading will exhibit higher stock return.

Contrarian: We argue that price reversal is closely related to the price momentum which supports the claim by Debondt and Thaler (1985) that when the length of the formation period and the holding period is between 3 to 5 years, the performance of the winner portfolio will be significantly worse than the loser portfolio. Other studies (Clare and Thomas, 1995; Dissanaike, 1997) have established evidence of a reversal effect over a two year period but not significant over a three year period. The reversal effect is a manifestation of the size effect. Some have argued that that contrarian emanates from wrong estimation by stocks analysts. For instance when low (high) analysts' expectations of future long term growth subsequently outperform (underperform) the market (Simon and Nowland, 2015; La Porta, 1996)

Calendar effect: Previous studies have established evidence indicating that declining stocks trade more frequently in December than better performing stocks and there are excess returns from trading the poor performing stocks in January (Dyl and Maberly, 1992; Roll, 1983). Keim (1983) examines the relationship between abnormal returns and market value (size) and concludes that the relation is more pronounced in January where almost $50 \%$ of the size effect happens; same result has been established in Australia (Brown, Keim, Kleidon and Marsh, 1983). 
Notwithstanding mixed results on momentum profits, there have been limited studies investigating the presence or absence of momentum effects in the emerging economies. Thus, this study is largely motivated to provide empirical evidence comparing or contrasting the existing literature. We apply the zero-cost trading strategy (Jegadeesh and Titman, 1993), which involves buying the past winners and selling the past losers, and long-term coverage (11 years) across the emerging BRICS economies.

\section{Data, methodology and hypotheses}

The data used in this study is for the emerging markets of BRICS, obtained from Reuters and DataStream. The sample period includes 11 years from January 2003 to December 2013. Daily closing prices are obtained and adjusted for dividend distribution and capital adjustment. There were a total of 3340 firm observations which were initially obtained from DataStream for the five emerging markets. However, stocks with less than 12 months trading history were excluded from the sample. This is to ensure that small and illiquid stocks or bidask bounce effects do not affect the validity of the results (Pathirawasam and Král', 2012). High volatility which is usually common in small and illiquid stocks may incur a bias against the significance on momentum profits ${ }^{1}$. Similar adjustment is made by Lehmann (1990), Jegadeesh and Titman (1993), Chan et al. (1999), Chui et al (2003), and Griffin et al (2005). Ouzounis et al (2009) find that portfolios can generate different abnormal returns depending on the methodology employed. Any approach, however, must exhibit a hybrid which is useful in achieving high forecast accuracy and therefore better returns (Kuma and Thenmozhi, 2014). Delisted stocks are also included in the sample for the purpose of solving survivorship bias problems as the results of the study tend to skew higher (Kothari, Shanken and Sloan, 1995; Chui et al, 2003). This yields a total sample of 3283 firms in the study.

The sample securities are ranked in ascending order on the quarterly basis of their past mean return: 3, 6, 9 and 12 months. Ten evenly-weighted portfolios are then held for 3, 6, 9 and 12 months which give a total of 16 investment strategies. We use the price momentum strategy for three reasons: first, most of the empirical results are reported using trading rules which are based on past prices. Second, a more powerful and prolonged effect can be found by using

\footnotetext{
${ }^{1}$ Additionally, serial correlation and underestimation of momentum returns can be avoided as caused by the bidask bounce effect when the first price of the post-ranking period and the last price of the ranking period are the same (Hon and Tonks, 2001).
} 
the price momentum strategy compared to earnings momentum strategy and thirdly, many studies examining the momentum effects are inspired by the approach of Jegadeesh and Titman (1993).

Momentum portfolio can be formed by the difference between the return of loser portfolio and the winner portfolio (W-L) in the holding period. In order to test whether these momentum profits are significant, t-tests are carried out for each winner-loser portfolio in these five emerging markets:

$\mathrm{H}_{0}: \mathrm{P}\left(\mathrm{R}_{\mathrm{W}, \mathrm{T}+\mathrm{K}}-\mathrm{R}_{\mathrm{L}, \mathrm{T}+\mathrm{K}}\right)=0$
$\mathrm{H}_{1}: \mathrm{P}\left(\mathrm{R}_{\mathrm{W}, \mathrm{T}+\mathrm{K}}-\mathrm{R}_{\mathrm{L}, \mathrm{T}+\mathrm{K}}\right)>0$

where

$\mathrm{R}_{\mathrm{W}, \mathrm{T}+\mathrm{K}}$ is the winner's return in the period of $\mathrm{T}+\mathrm{K}$

$\mathrm{R}_{\mathrm{L}, \mathrm{T}+\mathrm{K}}$ is the loser's return in the period of $\mathrm{T}+\mathrm{K}$

$\mathrm{T}+\mathrm{K}$ is the holding period

Our null hypotheses are stated as:

$\mathrm{H} 1=$ there is zero momentum profit on the winner-loser portfolio.

If the null hypothesis is not rejected, both the winners and losers will have the same average returns in the holding period. The alternative hypothesis is that momentum profit on the $\mathrm{W}-\mathrm{L}$ portfolio is significantly different from zero. If the null hypothesis is rejected (i.e. the alternative is true) then the winners will have higher returns than the losers in the holding period. The weak form of the efficient-market hypothesis $(\mathrm{EMH})$ will also be rejected assuming that are no transaction cost incurred. Hence, investors can earn abnormal profits from studying past stock price trends and we can conclude that the momentum effect is significant in particular country.

$\mathrm{H} 2$ = winner and loser portfolios will perform inertia in a certain time period.

$\mathrm{H} 3$ = price reversal is likely to appear in loser portfolio L than in the winner portfolio $\mathrm{W}$.

The t-statistic can be computed to show the significance of the mean return as:

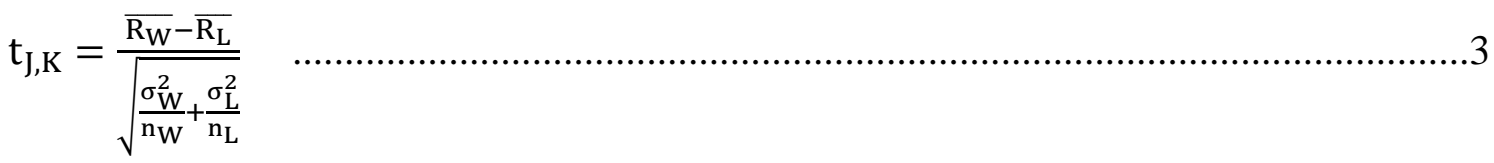


Where:

$\overline{\mathrm{R}_{\mathrm{W}}}$ is mean return of winner portfolio

$\overline{\mathrm{R}_{\mathrm{L}}}$ is mean return of loser portfolio

$\sigma_{\mathrm{W}}^{2}$ is the variance of winner portfolio

$\sigma_{\mathrm{L}}^{2}$ is the variance of loser portfolio

$\mathrm{n}_{\mathrm{w}}$ is the number of observations in winner portfolio

$\mathrm{n}_{\mathrm{L}}$ is the number of observations in loser portfolio

\section{Results and discussion of findings}

The empirical results are presented in five tables (Tables 1-5), one for each country. Each table has 12 strategies with different holding periods. Each Table reports, for each of the 60 strategies, the average monthly returns for winner portfolio, decile 2 to decile 9 portfolios, loser portfolio and winner-loser portfolio, and the t-statistic for the winner-loser portfolio. The results are significant if the mean returns are statistically different from zero at $10 \%$ $(t>1.644), 5 \% \quad(t>1.96)$ and $1 \% \quad(t>2.326)$ levels, respectively. The results are further illustrated graphically using the returns of winner, loser and momentum portfolios for each of the five emerging markets. We discuss the results of each market in turn.

\subsection{Empirical results for the Brazilian stock market and performance of winner and loser portfolios}

The first column of Table 1, which displays the result for Brazil, shows the formation period where the first row displays the holding period. For example, $(J=3, K=3)$ indicates the strategy that stocks are ranked according to their previous 3-months returns and then held for the next 3 months. Momentum or contrarian profits can be distinguished by calculating the difference between the returns of winner and loser portfolios. If the difference is statistically significantly lower (higher) than zero, contrarian (momentum) profits exist. Otherwise, no profit exists.

According to Table 1, the momentum portfolios are all statistically significant as all $\mathrm{t}$-values are above 1.644. Portfolios $\mathrm{S}(1,1), \mathrm{S}(3,1), \mathrm{S}(3,2), \mathrm{S}(3,3), \mathrm{S}(3,4)$, and $\mathrm{S}(3,5)$ have statistically 
significant contrarian profits. The rest of the 43 portfolios have statistically significant momentum profits. Portfolio $\mathrm{S}(9,11)$ yields the highest return with $0.82 \%(\mathrm{t}=5.7578)$ among the 60 strategies whereas portfolio $S(1,1)$ yields the lowest return with $-0.56 \% \quad(t=6.8496)$. Both portfolios' returns are significant at the $1 \%$ significance level. Our results support previous evidence (Muga and Santamaria, 2007; Abinzano, Muga and Santamaria, 2010) of intermediate to long horizon momentum effect for Brazil though there are negative returns between the formations periods 1 and 3 .

\section{[Insert Table 1 here]}

Figures 1 and 2 show the loser and winner portfolios performances respectively. They have a similar trend in abnormal returns as there is low variance for the returns of each of the strategies formed in the past 1, 3, 6, 9 and 12 months. Both portfolios yield similar returns and the majority lies between $1.5 \%$ and $3 \%$ respectively. Hence, the loser portfolios in Brazilian market yield a relatively high return as loser portfolios are assumed to have lower return than the market average.

Figure 1 shows that portfolio $\mathrm{S}(3,3)$ yields the highest returns (2.93\%) among all the combinations while portfolio $\mathrm{S}(3,12)$ yield the highest returns $(3.14 \%)$ as shown in Figure 2 (winner portfolio). The loser portfolios do not continue to earn high returns within the increasing holding period, as the reversal period starts from 3 months. The general trend for winner portfolios is going upward which shows that the inertia of winner portfolios lasts longer than the loser portfolios; the reversal effect is more appealing in loser portfolios. This indicates that the market has different reaction towards winner and loser portfolios and supports the Random Walk Hypothesis. Figure 3 shows no clear discerning trend of the momentum portfolio for the Brazilian market.

\section{[Insert Figures 1, 2 and 3 here]}

\subsection{Empirical results for the Russian stock market and performance of winner and loser portfolios}

Table 2 reports the results for the Russian stock market and shows that the majority of the momentum portfolio returns are insignificant while only portfolios $S(3,2), S(6,2)$ and $S(12,2)$ have statistically significant momentum effect. Portfolio $S(6,2)$ yields the highest significant return with $1.39 \%(\mathrm{t}=1.7692)$ whereas portfolio $\mathrm{S}(3,2)$ yields the lowest significant return with $0.41 \%(\mathrm{t}=1.8830)$. The returns of both these portfolios are only significant at the $10 \%$ significance level which is quite weak. The weak-form of EMH is hardly to be rejected in the 
Russian stock market as neither the momentum nor the contrarian effect is significant. The profitability of winner, loser and momentum strategy is higher with shorter formation and holding periods.

\section{[Insert Table 2 here]}

The average monthly returns for loser, winner and momentum portfolios of the Russian stock markets are represented graphically in Figures 4, 5 and 6 respectively. Figure 4 shows the patterns of loser portfolios which are formed in the past 1 to 12 months. The returns for the loser portfolios are high in the Russian market which majority lying between $4 \%$ and $6 \%$ and the highest return yield is $6.09 \%$. Figure 5 shows four flat lines representing winner portfolios formed from the past 3, 6, 9 and 12 months, majority of the yield return between $2 \%$ and $3 \%$ and the highest return yield is $7.29 \%$.

The majority of the loser portfolios returns decline over the 12 months holding period which shows that the inertia of loser portfolios lasts longer than winner portfolios. Figure 6 however shows an interesting pattern for the momentum portfolio returns. Although the five strategies have different shapes, they share one common characteristic which the momentum returns climb up sharply between 1 and 3 holding months but eventually drop back to the initial point of return over time.

The result therefore provides evidence that the prospect theory cannot explain the pattern of the performance of winner and loser portfolios in the Russian stock market. Rather, the market follows a Random Walk Hypothesis as depicted by Figures 5 and 6.

\section{[Insert Figures 4, 5 and 6 here]}

\subsection{Empirical results for the Indian stock market and performance of winner and loser portfolios}

Table 3 presents the results of the Indian stock market and shows that the returns for the loser portfolios, winner portfolios and momentum portfolios are all positive and statistically significant when implementing the 60 strategies. The $\mathrm{t}$-values are all above 1.96 which means that null hypothesis of zero momentum profit on the winner-loser portfolio is rejected. The weak-form of EMH is also rejected in the Indian stock market.

Portfolio $\mathrm{S}(1,1)$ yields the highest returns with 2.98\% ( $\mathrm{t}=14.3742)$ among the 60 strategies whereas portfolio $\mathrm{S}(12,10)$ yields the lowest returns with $0.0099 \%(\mathrm{t}=7.6939)$. Both portfolios' returns are significant at the $1 \%$ significance level. The overall results are consistent with 
previous studies (Griffin et al., 2003; Chui et al; 2010; Sehgal and Jain, 2011; Ansari and Khan, 2012) and higher than Sehgal and Balakrishnan (2002) who document the momentum return of 1.26 percent by using 12 months formation and holding period.

The positive momentum profits largely contribute to the winner portfolios since the returns for winner portfolios are exceptionally high which nearly double the returns for loser portfolios.

There is some probability that winners underreact more than losers in the market. This characteristic is in conformity with the behavioural model where investors overreact to particular incidents and underreact to public information signals. Our finding shows that momentum profit decreases when both formation period and holding period increase (Hon and Tonks, 2001; Jegadeesh and Titman, 1993; Sehgal, Jain, la Morandiere and Porteu, 2013). This gives a signal that the momentum profit in the Indian market may be due to its trending trajectory as India is a rising market in the global economy. This may favour momentum strategy. In fact, momentum strategy works when markets are trending upward and fails and may deliver negative returns when markets are trending downward (Naranjo and Porter, 2007; Urrutia and Vu, 2004).

\section{[Insert Table 3 here]}

Figure 7, 8 and 9 represent the performance of loser portfolios, winner portfolios and momentum portfolios, respectively, for the Indian stock market. The starting points for the loser portfolios are different which supports the Random Walk Hypothesis although they seem to converge after month 8 , their average monthly returns lie between $1.5-2$ percent respectively. The highest loser return is 2.2 percent with portfolio $S(12,2)$. The pattern for the winner portfolios is in good order as returns are diminishing in the ascending order of the formation period. For example, the overall returns of 1 month formation portfolio is higher than that of 3 months formation portfolio and 3 months formation portfolio is better performing than the 6 months formation period, and so forth. The returns of the winners decline inertly but they earn relatively higher returns than the losers.

Portfolios $\mathrm{S}(1,1)$ yields the highest winner returns with 4.31 percent. The pattern of the momentum portfolios is similar to that of the winner portfolios but is more diverse than winners. This can be explained by the reversal effect when the formation period increases. Our finding shows that the inertia of the winner portfolios lasts longer than that of loser 
portfolios, thus there is price reversal in loser portfolios which is consistent with the Random Walk Hypothesis.

\section{[Insert Figures 7, 8 and 9 here]}

\subsection{Empirical results for the Chinese stock market and performance of winner and loser portfolios}

Table 4 reports the results of the Chinese stock market and shows that the returns for the loser portfolios are positive when implementing the 60 strategies. Surprisingly, there are negative returns in the winner portfolios which are formed in the past 1 and 3 months as they do not continue to generate positive returns after holding periods. Only portfolios $\mathrm{S}(9,8), \mathrm{S}(9,9)$, $S(9,10) S(9,11)$ and $S(9,12)$ have statistically significant momentum profits. Portfolio $S(9,9)$ yields the highest returns with $0.15 \%(\mathrm{t}=3.1429)$ among the 60 strategies whereas portfolio $\mathrm{S}(6,1)$ yields the lowest returns with $-1.43 \%(\mathrm{t}=2.5378)$. Both portfolios' returns are significant at the $1 \%$ significance level. The results also show that 30 strategies which are formed in the past 1, 3, 6 and 12 months generate statistically significant contrarian profits. Kang et al (2002) and Wang and Chin (2004) find that similar momentum profits in the intermediate-horizon and contrarian profits exist in the short-horizon in the Chinese stock market using weekly data. In general, the returns of the Chinese market are mixed for the intermediate to long term.

One of the special features in Chinese market is that short sales are prohibited. Also the market is formed of many unsophisticated individual investors. Barberis et al: (1998) and Hong and Stein (1999) argue that momentum effect arises when the market is slow to renew or disseminate information. Investors hence overreact to special events (Nnadi, 2015) and underreact to any public announcement on market information.

\section{[Insert Table 4 here]}

The average monthly returns for loser, winner and momentum portfolios for the Chinese stock markets are represented graphically in Figures 10, 11 and 12, respectively. Figure 10 shows the patterns of loser portfolios, which are formed in the past 1 to 12 months. The returns decline significantly in the first 6 months but are steady in the latter 6 months and majority of the losers yield below 1 percent returns. Portfolio $S(6,1)$ yields the highest returns (1.99\%) among all the combinations. 
Figure 11 shows that the patterns of winner portfolios vary greatly from portfolio to portfolio. Portfolio $\mathrm{S}(9,1)$ yields the highest returns $(1.41 \%)$ among all the conjunctions. Two strategies with the formation period 1 and 3 months have negative returns until the holding period increases to month 8 . The result indicates that the winner portfolios perform worse than the losers. Figure 12 shows strategies with formation period of 1, 3, 6 and 12 months do not develop positive returns and are insignificant. Only formation period of 9 months acquire statistically positive returns after holding for five months. However, the momentum returns decrease with the increasing holding period, which supports the prospect theory assertion that individuals tend to derive satisfaction based on the potential outcomes and their respective probabilities.

\section{[Insert Figures 10, 11 and 12 here]}

\subsection{Empirical results for the South African stock market and performance of winner and loser portfolios}

Table 5 displays the results of the South Africa stock market and shows that 60 loser portfolios yield positive returns after holding for 4 months and 60 winner portfolios yield negative returns after holding for 2 months. Hence, past losers become future winners and past winners become future losers. Portfolios $\mathrm{S}(1,1), \mathrm{S}(1,2), \mathrm{S}(1,3) \mathrm{S}(6,1) \mathrm{S}(9,1) \mathrm{S}(9,2)$, $S(9,3), S(12,2)$ and $S(12,3)$ have statistically significant momentum profits where portfolio $\mathrm{S}(1,1)$ yields the highest returns with 3.03\% ( $\mathrm{t}=3.2241)$ among the 60 strategies and portfolio $\mathrm{S}(6,12)$ yields the lowest returns with $-1.76 \%(\mathrm{t}=2.9050)$. Both portfolios' returns are significant at the $1 \%$ significance level.

Our results find evidence that short-horizon momentum profit and intermediate to longhorizon contrarian are significant in the South African market. Similar study by Chui, Titman and Wei (2010) in the Johannesburg Stock Exchange finds significant momentum profit during 1981 to 2003 but they did not construct any portfolios studying different periods of the presence of momentum profit.

\section{[Insert Table 5 here]}

The average monthly returns for loser, winner and momentum portfolios for the South African stock markets are represented graphically in Figures 13, 14 and 15 respectively. Figure 13 shows that the patterns of loser portfolios which are formed in the past 1 to 12 
months are very similar to each other. There is a U-shaped trend in the first five months. The positive returns dramatically drop down to negative after the first month but eventually recovers to the initial level over time. Portfolio $\mathrm{S}(12,12)$ yields the highest returns $(0.89 \%)$ among all the combinations.

Figure 14 shows an L-shaped pattern for the winner portfolios which yield negative returns from holding for two months. Portfolio S(12,1) yields the highest returns (3.99\%) among all the combinations. Figure 15 also shows an L-shaped pattern for the momentum portfolios with contrarian profits dominate after holding for three months. Our result indicates that the trend of the winner portfolios is smoother than that of losers and the inertia of winners lasts longer than that of losers. The market reaction towards winner and loser portfolios is random in the South African market.

\section{[Insert Figures 13, 14 and 15 here]}

\section{Conclusion and recommendations}

The aim of this study is to investigate the nature of momentum or reversal effect for the five emerging markets: Brazil, Russia, India, China and South Africa. Sixty momentum strategies are constructed by investing in the past 1, 3, 6, 9 and 12 months and holding from periods of $1-12$ months. Our study imposes one month time-lag as monthly data is considered in all samples and the results are compared in each of the emerging market.

Our findings indicate that China shows significant short-horizon contrarian profit as well as significant intermediate to long-horizon momentum profit. This finding supports the existence of prospect theory in the Chinese stock market. The highest momentum return in Chinese market is portfolio $S(9,9)$ which yields $0.15 \%$ in return. This return, however, is not high enough to conclude that momentum strategy is feasible in the Chinese market. The portfolios of the other BRICS markets provide evidence of the Random Walk Hypothesis. Brazilian market performs better in terms of momentum profit although the returns are low. Portfolio $\mathrm{S}(9,11)$ earns the highest return $(0.82 \%)$.

The majority of the momentum portfolios in South Africa show reversal profit with the lowest return of $-1.76 \%$. These returns are high and strong which indicate that investors can earn abnormal profit from the South African market and Russia has neither momentum nor contrarian effect in its stock market. The Indian stock market, however, shows notably the results with all 60 strategies showing highly significant momentum returns. We find no 
evidence that bid-ask spread affect the significance of the short-term contrarian profits in Chinese and Russian stock markets but the remaining three markets generate spurious momentum without when no time-lag added when building the portfolios.

We find weak evidence to support some level of efficiency for the years 2003 to 2013 in the Russian market and reject the null hypothesis of zero momentum in the remaining four markets. Therefore, weak-form EMH cannot be held, as there are opportunities for arbitragers to extract abnormal returns from Brazil, India, China and South Africa. The findings indicate that the inertia of the winner portfolios lasts longer than loser portfolios which are more prone to price reversal which are identical to the behavioural financial theory. 


\section{References}

Abinzano, I., Muga, L., and Santamaria, R. (2010). The role of over-reaction and the disposition effect in explaining momentum in Latin American emerging markets. Inv. Econ 69 (273), 151-186

Ansari, V. A., and Khan, S. (2012). Momentum anomaly: evidence from India. Managerial Finance, 38(2): 206-223

Banz, Rolf W. (1981) The relationship between return and market value of common stock, Journal of Financial Economics, March, 3-18

Barberis, N., Shleifer A., and Vishny R. (1998). A model of investor sentiment, Journal of Financial Economics, 49 (3): 307-343

Biglova A., Jašić T., Rachev S., and Fabozzi F. J. (2004). Profitability of momentum strategies: Application of novel risk/return Ratio stock selection criteria. Investment Management and Financial Innovations, 47-61

Brown, P., Keim, D. B., Kleidon, A. W., and Marsh, T. A. (1983). Stock return seasonality and the tax-loss selling hypothesis: Analysis of the arguments and Australian evidence. Journal of Financial Economics, 12 (1): 105-127

Chan, L. K., Jegadeesh, N., \& Lakonishok, J. (1999). Momentum strategies. The Journal of Finance, 51 (5): 1681-1713

Chang, R.P., McLeavey, D.W., and Rhee, S.G (1995) Short-term abnormal returns of the contrarian strategy in the Japanese stock market. Journal of Business finance and Accounting, $22,1035-1048$

Chen H. (2003). On Characteristics Momentum. Journal of Behavioural Finance, 4(3):137156

Chen, Q., Hua, X.and Jiang, Y. (2015) Contrarian strategy and herding behaviour in the Chinese stock market. The European Journal of Finance,

DOI:10.1080/1351847X.2015.1071715

Cheng, J.W. and Wu, H (2010) The profitability of momentum trading strategies: Empirical evidence from Hong Kong. International Review of Economics \& Finance, 19(4), 527-538

Chui, A. C., Titman, S., and Wei, K. C. (2003). Intra-industry momentum: the case of REITs. Journal of Financial Markets, 6(3): 363-387

Chui, A. C., Titman, S., \& Wei, K. J. (2010). Individualism and momentum around the world. The Journal of Finance, 65(1), 361-392

Clare, A., and Thomas, S. (1995). The overreaction hypothesis and the UK stock market. Journal of Business Finance \& Accounting, 22(7): 961-973 
Conrad, J., and Kaul, G. (1998). An anatomy of trading strategies, The Review of Financial Studies, 11, 489-519

Debondt, W. F. M., and Thaler, R. (1985). Does the stock market overreact?, Journal of Finance, 40, 793-805

Dissanaike, G. (1997). Do stock market investors overreact?. Journal of Business Finance \& Accounting, 24 (1): 27-50

Dyl, E. A., and Maberly, E. D. (1992). Odd-lot transactions around the turn of the year and the January effect. Journal of Financial and Quantitative Analysis, 27 (4): 591-604

Edmister, R. O., and James, C. (1983). Is illiquidity a bar to buying small cap stocks? Journal of Portfolio Management, 9 (4): 14-19

Fama, E. (1970). "Efficient Capital Markets: A Review of Theory and Empirical Work". Journal of Finance, 25 (2): 383-417

Fama, E., and French, K. (1993). Common risk factors in the returns on stocks and bonds. Journal of financial economics, 33(1): 3-56

Forner, C., and Marhuenda, J. (2003). Contrarian and momentum strategies in the Spanish stock market. European Financial Management, 9(1): 67-88

Griffin, J. M., Ji, X., and Martin, J. S. (2005). Global momentum strategies. The Journal of Portfolio Management, 31(2): 23-39

Habib, U.R. and Hasan, M.M. (2012) Momentum Effect: Empirical Evidence from Karachi Stock Exchange. Available at http://pide.org.pk/psde/pdf/AGM28/Habir\%20Ur\%20Rahman\%20and\%20Hasan\%20M\%20 Mohsin.pdf. Last accessed 01/02/16

Hameed, A., \& Kusnadi, Y. (2002). Momentum strategies: Evidence from Pacific Basin stock markets. Journal of financial research, 25(3): 383-397

Hameed, A. and Ting, S. (2000) Trading volume and short-horizon contrarian profits: Evidence from the Malaysian market. Pacific-Basin Finance Journal 8(1), 67-84 •

Hon M., and Tonks I. (2001). Momentum in the UK Stock Market. Discussion papers / University of Bristol, Department of Economics , 516

Hong, H. and Stein, J. C. (1999), A Unified Theory of Underreaction, Momentum Trading, and Overreaction in Asset Markets. Journal of Finance, 54: 2143-2184

Jegadeesh, N., and Titman, S. (1993). Returns to buying winners and selling losers: Implications from stock market efficiency, Journal of Finance, 48, 65-91

Jostova, G.N, Statnislava, N., Alexander, P. and Stahel, C.N. (2013) Momentum in corporate bond returns. Review of Financial Studies 26(7),1649-1693 
Kahneman, D. and Tversky, A. (1979). Prospect Theory: An Analysis of Decision under Risk. Econometrica 47 (2): 263

Kang, J., Liu, M. H., and Ni, S. X. (2002). Contrarian and momentum strategies in the China stock market: 1993-2000. Pacific-Basin Finance Journal, 10 (3): 243-265

Keim, D. B. (1983). Size-related anomalies and stock return seasonality: Further empirical evidence. Journal of Financial Economics, 12 (1): 13-32

Kothari, S. P., Shanken, J., and Sloan, R. G. (1995). Another look at the cross-section of expected stock returns. Journal of Finance, 50 (1): 185-224

Kuma, M. and Thenmozhi, M. (2014) Forecasting stock index returns using ARIMA-SVM, ARIMA-ANN, and ARIMA-random forest hybrid models. International Journal of Banking, Accounting and Finance, (5 (3),284-308

La Porta, R. (1996) Expectations and the Cross-Section of Stock Returns. The Journal of Finance, 51 (5), 1715-1742.

Lehmann, B. (1990). Fads, martingales, and market efficiency. Quarterly Journal of Economics, 60, 1-28

Liu, W., Strong, N., and Xu, X. (2003). Post-earnings-announcement Drift in the UK. European Financial Management, 9 (1): 89-116

Marshall, B. R., and Cahan, R. M. (2005). Is the 52-week high momentum strategy profitable outside the US? Applied Financial Economics, 15(18): 1259-1267

Muga, L., and Santamaria, R. (2007). The momentum effect in Latin American emerging markets. Emerging Markets Finance and Trade, 43(4): 24-45

Naranjo, A. and Porter,B. (2007) Including emerging markets in international momentum investment strategies. Emerging Markets Review , 8, 147- 166

Nnadi, M. (2015) Stock market reaction, financial reporting quality and International Financial Reporting Standards (IFRS) convergence of listed firms in China. Global Business and Economics Review, 17(4), 399 - 416

Nnadi, M., Omoteso, K. and Yu, Y. (2015) Does Regulatory Environment affect Earnings Management in Transitional Economies? An Empirical Examination of the Financial Reporting Quality of Cross-Listed Firms of China and Hong Kong (in) Rustam Jamilov, Yusaf H. Akbar (ed.) Neo-Transitional Economics . International Finance Review, 16, 245279

Okunev, J., and White, D. (2003). Do momentum-based strategies still work in foreign currency markets? Journal of Financial and Quantitative Analysis, 38(2): 425-448

Osborne, M. F. M. (1959). Brownian motion in the stock market, Operations Research, 7, 145-173. 
Ouzounis, G., Gaganis, C. and Zopounidis, C. (2009) Prediction of acquisitions and portfolio returns. International Journal of Banking, Accounting and Finance 1(4), 381-406

Pathirawasam, C. and Král', M. (2012) Momentum effect and market states: Emerging market evidence. E+M Ekonomie a Management. 15 (2), 115-124

Roll, R. (1981). A possible explanation of the small firm effect. Journal of Finance, 36 (4): 879-888

Roll, R. (1983). Vas ist das? The Journal of Portfolio Management, 9 (2): 18-28

Schiereck, D., De Bondt, W., and Weber, M. (1999). Contrarian and momentum strategies in Germany. Financial Analysts Journal: 104-116

Sehgal, S., and Balakrishnan, I. (2002). Contrarian and momentum strategies in the Indian capital market. Vikalpa, 27(1): 13-20

Sehgal, S., and Jain, S. (2011). Short-term momentum patterns in stock and sectoral returns: evidence from India. Journal of Advances in Management Research, 8(1): 99-122

Sehgal, S., Jain, S., la Morandiere, D., and Porteu, L. (2013). Long-Term Prior Return Patterns in Stock Returns: Evidence from Emerging Markets. International Journal of Business \& Finance Research (IJBFR), 7(2): 53-78

Simon, A. and Nowland, J. (2015) Long-term growth forecasts and stock recommendation profitability. Asia-Pacific Journal of Accounting \& Economics, 22(2), 163-190

Tversky, A. and Kahneman, D. (1986). Rational Choice and the Framing of Decisions. The Journal of Business 59 (4): 251-267

Tversky, A. and Kahneman, D. (1992). Advances in prospect theory: Cumulative representation of uncertainty. Journal of Risk and Uncertainty 5 (4): 297-323

Thaler, R. (1999). Mental accounting matters. Journal of Behavioural decision making, 12(3): $183-206$

Urrutia, J., and Vu, J. D. (2004). Do momentum strategies generate profits in emerging stock markets? Unpublished Mimeograph, Pennsylvania University

Wang, C., \& Chin, S. (2004). Profitability of return and volume-based investment strategies in China's stock market. Pacific-Basin Finance Journal, 12(5), 541-564

Wu, R. and Lin, H.W. (2013) Security analysts' incentive and cognitive processing bias: evidence from analysts' recommendations. Asia-Pacific Journal of Accounting \& Economics, 21 (4), 443-471

World Bank (2006) The Road to 2050: Sustainable development for the $21^{\text {st }}$ century. Washington, DC, The World Bank 


\section{Table 1: Average monthly return from 2003 to 2013 in Brazil (one month lag)}

Table 1 reports average monthly returns for 60 momentum strategies from January 2003 to December 2013 in Brazilian stock markets. Each stock which is ranked and arranged into 10 equal deciles in the light of the past 1, 3, 6, 9 and 12 months and is simultaneously held for $1-12$ months. Winner (loser) portfolio is the top (bottom) deciles marked as Winner (Loser). The difference between the two portfolios is the momentum portfolio, marked as Winner-Loser. For each of the 60 strategies, the average monthly returns for winner portfolio, decile 2 to decile 9 portfolios, loser portfolio and winner-loser portfolio, and the t-statistic in bracket for the winner-loser portfolio.

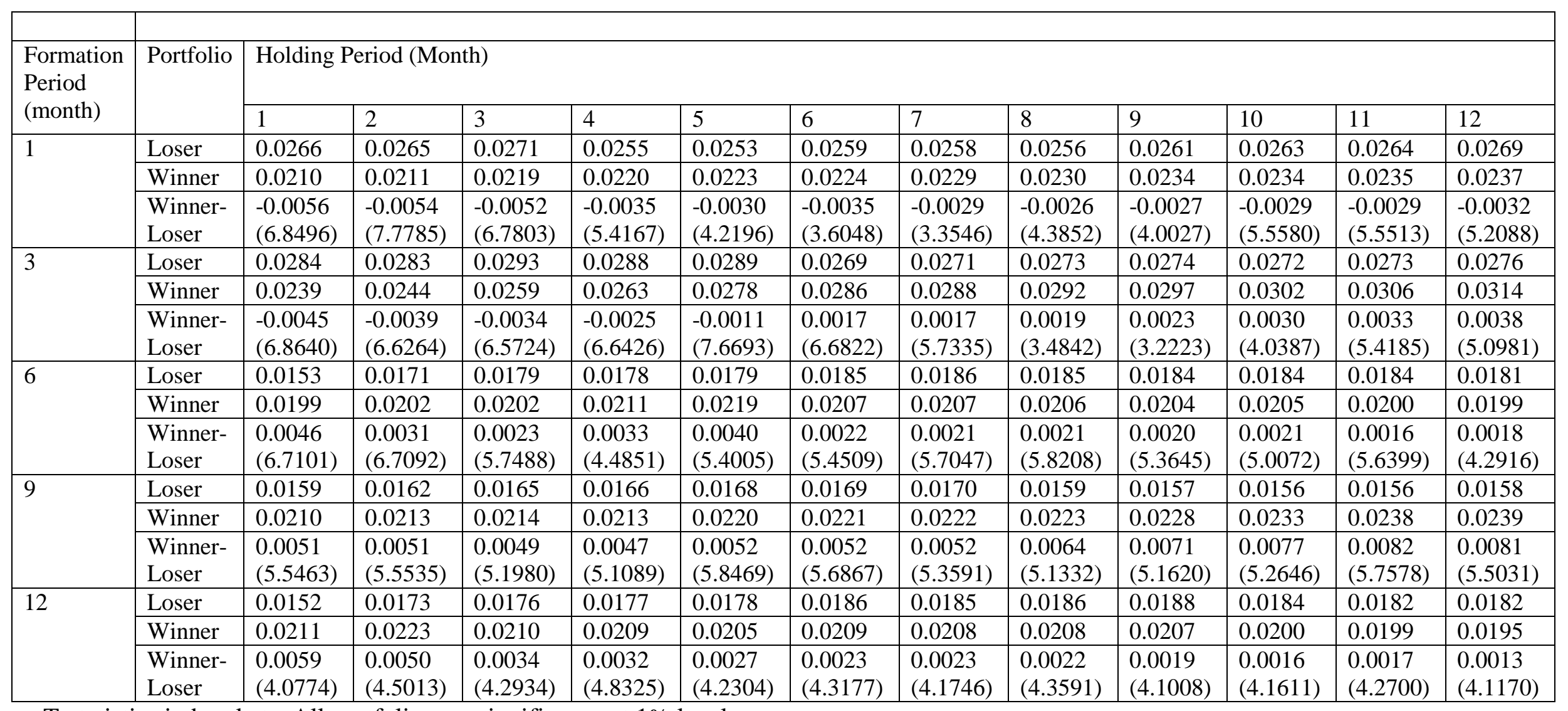

T-statistics in brackets. All portfolios are significance at $1 \%$ level 
Table 2: Average monthly return from 2003 to 2013 in Russia (one month lag)

Table 2 shows average monthly returns for 60 momentum strategies from January 2003 to December 2013 in the Russian stock market. Each stock which is ranked and arranged into 10 equal deciles in the light of the past 1, 3, 6, 9 and 12 months and is simultaneously held for 1-12 months. For each of the 60 strategies, the average monthly returns for winner portfolio, decile 2 to decile 9 portfolios, loser portfolio and winner-loser portfolio, and the t-statistic in bracket for the winner-loser portfolio.

\begin{tabular}{|c|c|c|c|c|c|c|c|c|c|c|c|c|c|}
\hline \multirow{2}{*}{$\begin{array}{l}\text { Formation } \\
\text { Period } \\
\text { (month) }\end{array}$} & \multirow[t]{2}{*}{ Portfolio } & \multicolumn{12}{|c|}{ Holding Period (Month) } \\
\hline & & 1 & 2 & 3 & 4 & 5 & 6 & 7 & 8 & 9 & 10 & 11 & 12 \\
\hline \multirow[t]{3}{*}{1} & Loser & 0.0609 & 0.0576 & 0.0570 & 0.0566 & 0.0560 & 0.0559 & 0.0558 & 0.0557 & 0.0549 & 0.0548 & 0.0546 & 0.0545 \\
\hline & Winner & 0.0610 & 0.0614 & 0.0615 & 0.0616 & 0.0719 & 0.0729 & 0.0713 & 0.0710 & 0.0601 & 0.0621 & 0.0601 & 0.0541 \\
\hline & $\begin{array}{l}\text { Winner- } \\
\text { Loser }\end{array}$ & $\begin{array}{l}0.0010 \\
(0.4560) \\
\end{array}$ & $\begin{array}{l}0.0038 \\
(0.2880) \\
\end{array}$ & $\begin{array}{l}0.0045 \\
(0.8460) \\
\end{array}$ & $\begin{array}{l}0.0050 \\
(0.8631) \\
\end{array}$ & $\begin{array}{l}0.0159 \\
(0.8874) \\
\end{array}$ & $\begin{array}{l}0.0170 \\
(0.8595) \\
\end{array}$ & $\begin{array}{l}0.0155 \\
(0.7650) \\
\end{array}$ & $\begin{array}{l}0.0153 \\
(0.7267) \\
\end{array}$ & $\begin{array}{l}0.0052 \\
(0.3250) \\
\end{array}$ & $\begin{array}{l}0.0073 \\
(0.5369) \\
\end{array}$ & $\begin{array}{l}0.0055 \\
(0.2106) \\
\end{array}$ & $\begin{array}{l}-0.0004 \\
(0.2301) \\
\end{array}$ \\
\hline \multirow[t]{3}{*}{3} & Loser & 0.0599 & 0.0561 & 0.0555 & 0.0551 & 0.0548 & 0.0542 & 0.0541 & 0.0541 & 0.0539 & 0.0539 & 0.0538 & 0.0537 \\
\hline & Winner & 0.0600 & 0.0602 & 0.0593 & 0.0593 & 0.0582 & 0.0571 & 0.0570 & 0.0563 & 0.0561 & 0.0551 & 0.0549 & 0.0532 \\
\hline & $\begin{array}{l}\text { Winner- } \\
\text { Loser }\end{array}$ & $\begin{array}{l}0.0001 \\
(1.2415)\end{array}$ & $\begin{array}{l}0.0041 \\
(1.8830)^{*}\end{array}$ & $\begin{array}{l}0.0038 \\
(0.6556)\end{array}$ & $\begin{array}{l}0.0042 \\
(0.1463)\end{array}$ & $\begin{array}{l}0.0034 \\
(0.1122)\end{array}$ & $\begin{array}{l}0.0029 \\
(0.1474)\end{array}$ & $\begin{array}{l}0.0029 \\
(0.8459)\end{array}$ & $\begin{array}{l}0.0022 \\
(0.5940)\end{array}$ & $\begin{array}{l}0.0022 \\
(0.8206)\end{array}$ & $\begin{array}{l}0.0012 \\
(0.4917)\end{array}$ & $\begin{array}{l}0.0011 \\
(0.7788)\end{array}$ & $\begin{array}{l}-0.0005 \\
(0.9262)\end{array}$ \\
\hline \multirow[t]{3}{*}{6} & Loser & 0.0499 & 0.0463 & 0.0458 & 0.0452 & 0.0449 & 0.0442 & 0.0441 & 0.0442 & 0.0437 & 0.0438 & 0.0435 & 0.0432 \\
\hline & Winner & 0.0611 & 0.0602 & 0.0573 & 0.0569 & 0.0571 & 0.0570 & 0.0564 & 0.0561 & 0.0549 & 0.0541 & 0.0532 & 0.0523 \\
\hline & $\begin{array}{l}\text { Winner- } \\
\text { Loser }\end{array}$ & $\begin{array}{l}0.0112 \\
(0.5170) \\
\end{array}$ & $\begin{array}{l}0.0139 \\
(1.7692)^{*}\end{array}$ & $\begin{array}{l}0.0115 \\
(0.7480) \\
\end{array}$ & $\begin{array}{l}0.0117 \\
(0.6270) \\
\end{array}$ & $\begin{array}{l}0.0122 \\
(0.2486) \\
\end{array}$ & $\begin{array}{l}0.0128 \\
(0.4004)\end{array}$ & $\begin{array}{l}0.0123 \\
(0.6237) \\
\end{array}$ & $\begin{array}{l}0.0119 \\
(0.2970) \\
\end{array}$ & $\begin{array}{l}0.0112 \\
(0.2596) \\
\end{array}$ & $\begin{array}{l}0.0103 \\
(0.2090) \\
\end{array}$ & $\begin{array}{l}0.0097 \\
(0.3608) \\
\end{array}$ & $\begin{array}{l}0.0091 \\
(0.4697) \\
\end{array}$ \\
\hline \multirow[t]{3}{*}{9} & Loser & 0.0503 & 0.0472 & 0.0463 & 0.0458 & 0.0453 & 0.0453 & 0.0444 & 0.0445 & 0.0446 & 0.0441 & 0.0437 & 0.0431 \\
\hline & Winner & 0.0522 & 0.0524 & 0.0526 & 0.0529 & 0.0538 & 0.0544 & 0.0537 & 0.0531 & 0.0526 & 0.0519 & 0.0503 & 0.0501 \\
\hline & $\begin{array}{l}\text { Winner- } \\
\text { Loser }\end{array}$ & $\begin{array}{l}0.0019 \\
(0.2761)\end{array}$ & $\begin{array}{l}0.0052 \\
(0.2299)\end{array}$ & $\begin{array}{l}0.0063 \\
(0.2266)\end{array}$ & $\begin{array}{l}0.0071 \\
(0.7590)\end{array}$ & $\begin{array}{l}0.0085 \\
(0.1166)\end{array}$ & $\begin{array}{l}0.0091 \\
(0.5819)\end{array}$ & $\begin{array}{l}0.0093 \\
(0.6270)\end{array}$ & $\begin{array}{l}0.0086 \\
(0.5940)\end{array}$ & $\begin{array}{l}0.0080 \\
(0.0990)\end{array}$ & $\begin{array}{l}0.0078 \\
(0.6930)\end{array}$ & $\begin{array}{l}0.0066 \\
(0.1397) \\
\end{array}$ & $\begin{array}{l}0.0070 \\
(0.3861)\end{array}$ \\
\hline \multirow[t]{3}{*}{12} & Loser & 0.0454 & 0.0459 & 0.0452 & 0.0459 & 0.0453 & 0.0458 & 0.0469 & 0.0462 & 0.0469 & 0.0471 & 0.0477 & 0.0478 \\
\hline & Winner & 0.0521 & 0.0513 & 0.0508 & 0.0500 & 0.0491 & 0.0484 & 0.0481 & 0.0480 & 0.0478 & 0.0475 & 0.0469 & 0.0468 \\
\hline & $\begin{array}{l}\text { Winner- } \\
\text { Loser }\end{array}$ & $\begin{array}{l}0.0067 \\
(0.9504)\end{array}$ & $\begin{array}{l}0.0054 \\
(1.7065)^{*}\end{array}$ & $\begin{array}{l}0.0056 \\
(0.6006)\end{array}$ & $\begin{array}{l}0.0041 \\
(0.5600)\end{array}$ & $\begin{array}{l}0.0038 \\
(0.7722) \\
\end{array}$ & $\begin{array}{l}0.0026 \\
(1.0494) \\
\end{array}$ & $\begin{array}{l}0.0012 \\
(0.9900)\end{array}$ & $\begin{array}{l}0.0018 \\
(0.6600) \\
\end{array}$ & $\begin{array}{l}0.0009 \\
(0.4224)\end{array}$ & $\begin{array}{l}0.0004 \\
(0.7370)\end{array}$ & $\begin{array}{l}-0.0008 \\
(0.3432) \\
\end{array}$ & $\begin{array}{l}-0.0010 \\
(0.9614) \\
\end{array}$ \\
\hline
\end{tabular}

T-statistics in brackets. * significant at the $10 \%$ significance level 
Table 3: Average Monthly Return From 2003 to 2013 in India (one month lag)

Table 3 reports the average monthly returns for 60 momentum strategies from January 2003 to December 2013 in Indian stock markets. Each stock which is ranked and arranged into 10 equal deciles in the light of the past 1, 3, 6, 9 and 12 months and is simultaneously held for 1-12 months. For each of the 60 strategies, two major statistics are shown: the average monthly returns for winner portfolio, decile 2 to decile 9 portfolios, loser portfolio and winner-loser portfolio, and the t-statistic for the winner-loser portfolio.

\begin{tabular}{|c|c|c|c|c|c|c|c|c|c|c|c|c|c|}
\hline \multirow{2}{*}{$\begin{array}{l}\text { Formation } \\
\text { Period } \\
\text { (month) }\end{array}$} & \multirow[t]{2}{*}{ Portfolio } & \multicolumn{12}{|c|}{ Holding Period (Month) } \\
\hline & & 1 & 2 & 3 & 4 & 5 & 6 & 7 & 8 & 9 & 10 & 11 & 12 \\
\hline \multirow[t]{3}{*}{1} & Loser & 0.0133 & 0.0149 & 0.0159 & 0.0185 & 0.0182 & 0.0186 & 0.0163 & 0.0159 & 0.0159 & 0.0160 & 0.0160 & 0.0158 \\
\hline & Winner & 0.0431 & 0.0383 & 0.0379 & 0.0384 & 0.0381 & 0.0385 & 0.0356 & 0.0359 & 0.0362 & 0.0349 & 0.0343 & 0.0352 \\
\hline & $\begin{array}{l}\text { Winner- } \\
\text { Loser }\end{array}$ & $\begin{array}{l}0.0298 \\
(14.37 \\
42) \\
\end{array}$ & $\begin{array}{l}0.0234 \\
(14.6061)\end{array}$ & $\begin{array}{l}0.0220 \\
(15.8149)\end{array}$ & $\begin{array}{l}0.0199 \\
(15.1972)\end{array}$ & $\begin{array}{l}0.0199 \\
(14.0726)\end{array}$ & $\begin{array}{l}0.0199 \\
(14.0510)\end{array}$ & $\begin{array}{l}0.0193 \\
(13.4023)\end{array}$ & $\begin{array}{l}0.0200 \\
(13.0018)\end{array}$ & $\begin{array}{l}0.0203 \\
(11.8811)\end{array}$ & $\begin{array}{l}0.0189 \\
(10.5256)\end{array}$ & $\begin{array}{l}0.0183 \\
(10.1737)\end{array}$ & $\begin{array}{l}0.0194 \\
(10.0459)\end{array}$ \\
\hline \multirow[t]{3}{*}{3} & Loser & 0.0132 & 0.0149 & 0.0156 & 0.0133 & 0.0130 & 0.0129 & 0.0128 & 0.0169 & 0.0165 & 0.0161 & 0.0165 & 0.0161 \\
\hline & Winner & 0.0420 & 0.0390 & 0.0369 & 0.0363 & 0.0361 & 0.0360 & 0.0359 & 0.0339 & 0.0334 & 0.0329 & 0.0325 & 0.0320 \\
\hline & $\begin{array}{l}\text { Winner- } \\
\text { Loser }\end{array}$ & $\begin{array}{l}0.0288 \\
(11.07 \\
38)\end{array}$ & $\begin{array}{l}0.0241 \\
(12.3366)\end{array}$ & $\begin{array}{l}0.0213 \\
(12.2979)\end{array}$ & $\begin{array}{l}0.0230 \\
(12.6552)\end{array}$ & $\begin{array}{l}0.0231 \\
(11.3429)\end{array}$ & $\begin{array}{l}0.0231 \\
(13.5553)\end{array}$ & $\begin{array}{l}0.0231 \\
(12.8424)\end{array}$ & $\begin{array}{l}0.0170 \\
(12.3924)\end{array}$ & $\begin{array}{l}0.0169 \\
(11.0144)\end{array}$ & $\begin{array}{l}0.0168 \\
(11.6759)\end{array}$ & $\begin{array}{l}0.0160 \\
(9.0432)\end{array}$ & $\begin{array}{l}0.0159 \\
(11.7245)\end{array}$ \\
\hline \multirow[t]{3}{*}{6} & Loser & 0.0213 & 0.0200 & 0.0193 & 0.0199 & 0.0167 & 0.0169 & 0.0169 & 0.0172 & 0.0170 & 0.0160 & 0.0160 & 0.0158 \\
\hline & Winner & 0.0401 & 0.0360 & 0.0334 & 0.0333 & 0.0300 & 0.0310 & 0.0303 & 0.0311 & 0.0312 & 0.0299 & 0.0298 & 0.0296 \\
\hline & $\begin{array}{l}\text { Winner- } \\
\text { Loser }\end{array}$ & $\begin{array}{l}0.0188 \\
(10.65 \\
79)\end{array}$ & $\begin{array}{l}0.0160 \\
(10.4374)\end{array}$ & $\begin{array}{l}0.0141 \\
(11.8208)\end{array}$ & $\begin{array}{l}0.0134 \\
(10.4707)\end{array}$ & $\begin{array}{l}0.0133 \\
(9.3456)\end{array}$ & $\begin{array}{l}0.0141 \\
(9.8217)\end{array}$ & $\begin{array}{l}0.0134 \\
(10.7884)\end{array}$ & $\begin{array}{l}0.0139 \\
(11.6021)\end{array}$ & $\begin{array}{l}0.0142 \\
(12.5436)\end{array}$ & $\begin{array}{l}0.0139 \\
(12.7524)\end{array}$ & $\begin{array}{l}0.0138 \\
(10.0315)\end{array}$ & $\begin{array}{l}0.0138 \\
(10.1287)\end{array}$ \\
\hline \multirow[t]{3}{*}{9} & Loser & 0.0180 & 0.0180 & 0.0185 & 0.0201 & 0.0168 & 0.0160 & 0.0189 & 0.0183 & 0.0171 & 0.0174 & 0.0171 & 0.0169 \\
\hline & Winner & 0.0359 & 0.0340 & 0.0333 & 0.0344 & 0.0312 & 0.0301 & 0.0309 & 0.0310 & 0.0300 & 0.0296 & 0.0294 & 0.0291 \\
\hline & $\begin{array}{l}\text { Winner- } \\
\text { Loser }\end{array}$ & $\begin{array}{l}0.0179 \\
(9.203 \\
4)\end{array}$ & $\begin{array}{l}0.0160 \\
(9.2124)\end{array}$ & $\begin{array}{l}0.0148 \\
(9.7425)\end{array}$ & $\begin{array}{l}0.0143 \\
(10.2448)\end{array}$ & $\begin{array}{l}0.0144 \\
(8.7209)\end{array}$ & $\begin{array}{l}0.0141 \\
(8.7191)\end{array}$ & $\begin{array}{l}0.0120 \\
(9.7839)\end{array}$ & $\begin{array}{l}0.0127 \\
(9.7713)\end{array}$ & $\begin{array}{l}0.0129 \\
(9.4788)\end{array}$ & $\begin{array}{l}0.0122 \\
(9.67860\end{array}$ & $\begin{array}{l}0.0123 \\
(8.2304)\end{array}$ & $\begin{array}{l}0.0122 \\
(7.4851)\end{array}$ \\
\hline \multirow[t]{3}{*}{12} & Loser & 0.0210 & 0.0220 & 0.0210 & 0.0196 & 0.0198 & 0.0185 & 0.0173 & 0.0172 & 0.0172 & 0.0184 & 0.0183 & 0.0176 \\
\hline & Winner & 0.0381 & 0.0361 & 0.0331 & 0.0319 & 0.0308 & 0.0303 & 0.0292 & 0.0291 & 0.0284 & 0.0283 & 0.0284 & 0.0283 \\
\hline & $\begin{array}{l}\text { Winner- } \\
\text { Loser }\end{array}$ & $\begin{array}{l}0.0171 \\
(9.442 \\
8) \\
\end{array}$ & $\begin{array}{l}0.0141 \\
(9.8343)\end{array}$ & $\begin{array}{l}0.0121 \\
(8.0522)\end{array}$ & $\begin{array}{l}0.0123 \\
(8.8127)\end{array}$ & $\begin{array}{l}0.0110 \\
(8.4779)\end{array}$ & $\begin{array}{l}0.0118 \\
(8.8181)\end{array}$ & $\begin{array}{l}0.0119 \\
(7.0117)\end{array}$ & $\begin{array}{l}0.0119 \\
(7.0702)\end{array}$ & $\begin{array}{l}0.0112 \\
(7.7587)\end{array}$ & $\begin{array}{l}0.0099 \\
(7.6939)\end{array}$ & $\begin{array}{l}0.0101 \\
(7.8154)\end{array}$ & $\begin{array}{l}0.0107 \\
(7.6444)\end{array}$ \\
\hline
\end{tabular}

T-statistics in brackets. All portfolios' returns are significant at the $1 \%$ significance level. 


\section{Table 4 : Average Monthly Return from 2003 to 2013 in China (one month lag)}

Table 4 is the average monthly returns for 60 momentum strategies from January 2003 to December 2013 in Chinese stock markets. Each stock is ranked and arranged into 10 equal deciles in the light of the past 1, 3, 6, 9 and 12 months and is simultaneously held for $1-12$ months. For each of the 60 strategies, two major statistics are shown: the average monthly returns for winner portfolio, decile 2 to decile 9 portfolios, loser portfolio and winner-loser portfolio, and the $\mathrm{t}$ statistic for the winner-loser portfolio are shown.

\begin{tabular}{|c|c|c|c|c|c|c|c|c|c|c|c|c|c|}
\hline \multirow{2}{*}{$\begin{array}{l}\text { Formati } \\
\text { on } \\
\text { Period } \\
\text { (month) }\end{array}$} & \multirow{2}{*}{$\begin{array}{l}\text { Portfoli } \\
\text { o }\end{array}$} & \multicolumn{12}{|c|}{ Holding Period (Month) } \\
\hline & & 1 & 2 & 3 & 4 & 5 & 6 & 7 & 8 & 9 & 10 & 11 & 12 \\
\hline \multirow[t]{3}{*}{1} & Loser & 0.0187 & 0.0096 & 0.0071 & 0.0056 & 0.0051 & 0.0039 & 0.0033 & 0.0027 & 0.0025 & 0.0026 & 0.0030 & 0.0028 \\
\hline & Winner & 0.0063 & 0.0006 & 0.0001 & -0.0013 & -0.0019 & -0.0010 & -0.0006 & 0.0004 & 0.0008 & 0.0008 & 0.0012 & 0.0015 \\
\hline & $\begin{array}{l}\text { Winner- } \\
\text { Loser }\end{array}$ & $\begin{array}{l}-0.0124 \\
(2.0547) * *\end{array}$ & $\begin{array}{l}-0.0091 \\
(2.4797) * *\end{array}$ & $\begin{array}{l}-0.0070 \\
(2.6004) * *\end{array}$ & $\begin{array}{l}-0.0069 \\
(3.4423)^{* *}\end{array}$ & $\begin{array}{l}-0.0069 \\
(4.2300)^{* *}\end{array}$ & $\begin{array}{l}-0.0050 \\
(3.6042) * *\end{array}$ & $\begin{array}{l}-0.0038 \\
(3.0134) * *\end{array}$ & $\begin{array}{l}-0.0023 \\
(1.9940) * *\end{array}$ & $\begin{array}{l}-0.0017 \\
(1.5314)\end{array}$ & $\begin{array}{l}-0.0018 \\
(1.6393)\end{array}$ & $\begin{array}{l}-0.0018 \\
(1.5889)\end{array}$ & $\begin{array}{l}-0.0013 \\
(1.2213)\end{array}$ \\
\hline \multirow[t]{3}{*}{3} & Loser & 0.0182 & 0.0084 & 0.0057 & 0.0043 & 0.0051 & 0.0029 & 0.0025 & 0.0023 & 0.0025 & 0.0027 & 0.0032 & 0.0032 \\
\hline & Winner & 0.0040 & -0.0015 & -0.0022 & -0.0021 & -0.0019 & -0.0006 & -0.0001 & 0.0005 & 0.0008 & 0.0009 & 0.0013 & 0.0010 \\
\hline & $\begin{array}{l}\text { Winner- } \\
\text { Loser }\end{array}$ & $\begin{array}{l}-0.0142 \\
(3.0702)^{* *}\end{array}$ & $\begin{array}{l}-0.0099 \\
(3.2810) * *\end{array}$ & $\begin{array}{l}-0.0079 \\
(3.7549) * *\end{array}$ & $\begin{array}{l}-0.0063 \\
(3.4978)^{* *}\end{array}$ & $\begin{array}{l}-0.0069 \\
(4.2300) * *\end{array}$ & $\begin{array}{l}-0.0036 \\
(2.4342) * *\end{array}$ & $\begin{array}{l}-0.0026 \\
(1.9117) *\end{array}$ & $\begin{array}{l}-0.0018 \\
(1.4056) \\
\end{array}$ & $\begin{array}{l}-0.0017 \\
(1.4438) \\
\end{array}$ & $\begin{array}{l}-0.0018 \\
(1.6043) \\
\end{array}$ & $\begin{array}{l}-0.0019 \\
(1.6028) \\
\end{array}$ & $\begin{array}{l}-0.0022 \\
(1.9107)^{*}\end{array}$ \\
\hline \multirow[t]{3}{*}{6} & Loser & 0.0199 & 0.0114 & 0.0077 & 0.0059 & 0.0047 & 0.0041 & 0.0037 & 0.0038 & 0.0043 & 0.0046 & 0.0052 & 0.0051 \\
\hline & Winner & 0.0056 & 0.0005 & 0.0007 & 0.0011 & 0.0015 & 0.0018 & 0.0024 & 0.0027 & 0.0025 & 0.0024 & 0.0026 & 0.0022 \\
\hline & $\begin{array}{l}\text { Winner- } \\
\text { Loser }\end{array}$ & $\begin{array}{l}-0.0143 \\
(2.5378) * *\end{array}$ & $\begin{array}{l}-0.0109 \\
(3.1159) * *\end{array}$ & $\begin{array}{l}-0.0070 \\
(2.5512) * *\end{array}$ & $\begin{array}{l}-0.0047 \\
(1.9682) * *\end{array}$ & $\begin{array}{l}-0.0032 \\
(1.503) \\
\end{array}$ & $\begin{array}{l}-0.0023 \\
(1.210) \\
\end{array}$ & $\begin{array}{l}-0.0013 \\
(0.7408) \\
\end{array}$ & $\begin{array}{l}-0.0011 \\
(0.6932) \\
\end{array}$ & $\begin{array}{l}-0.0018 \\
(1.2008) \\
\end{array}$ & $\begin{array}{l}-0.0022 \\
(1.5017) \\
\end{array}$ & $\begin{array}{l}-0.0026 \\
(1.6820)^{*}\end{array}$ & $\begin{array}{l}-0.0029 \\
(2.0349) * *\end{array}$ \\
\hline \multirow[t]{3}{*}{9} & Loser & 0.0153 & 0.0087 & 0.0077 & 0.0067 & 0.0058 & 0.0052 & 0.0050 & 0.0047 & 0.0046 & 0.0046 & 0.0050 & 0.0047 \\
\hline & Winner & 0.0141 & 0.0088 & 0.0068 & 0.0065 & 0.0061 & 0.0057 & 0.0057 & 0.0060 & 0.0061 & 0.0059 & 0.0061 & 0.0057 \\
\hline & $\begin{array}{l}\text { Winner- } \\
\text { Loser }\end{array}$ & $\begin{array}{l}-0.0012 \\
(0.6216) \\
\end{array}$ & $\begin{array}{l}0.0001 \\
(0.0514) \\
\end{array}$ & $\begin{array}{l}-0.0009 \\
(0.9819) \\
\end{array}$ & $\begin{array}{l}-0.0002 \\
(0.2443) \\
\end{array}$ & $\begin{array}{l}0.0003 \\
(0.3682) \\
\end{array}$ & $\begin{array}{l}0.0005 \\
(0.7645) \\
\end{array}$ & $\begin{array}{l}0.0007 \\
(1.1948) \\
\end{array}$ & $\begin{array}{l}0.0013 \\
(2.4504)^{* *}\end{array}$ & $\begin{array}{l}0.0015 \\
(3.1429) * * \\
\end{array}$ & $\begin{array}{l}0.0013 \\
(2.6673) * * \\
\end{array}$ & $\begin{array}{l}0.0011 \\
(2.1005)^{* *}\end{array}$ & $\begin{array}{l}0.0010 \\
(2.0190)^{* * *}\end{array}$ \\
\hline \multirow[t]{3}{*}{12} & Loser & 0.0194 & 0.0087 & 0.0091 & 0.0076 & 0.0070 & 0.0062 & 0.0059 & 0.0057 & 0.0058 & 0.0061 & 0.0068 & 0.0067 \\
\hline & Winner & 0.0121 & 0.0054 & 0.0041 & 0.0037 & 0.0035 & 0.0030 & 0.0029 & 0.0028 & 0.0025 & 0.0025 & 0.0029 & 0.0027 \\
\hline & $\begin{array}{l}\text { Winner- } \\
\text { Loser }\end{array}$ & $\begin{array}{l}-0.0073 \\
(1.2962)\end{array}$ & $\begin{array}{l}-0.0063 \\
(1.7330)^{*}\end{array}$ & $\begin{array}{l}-0.0051 \\
(1.7934)^{*}\end{array}$ & $\begin{array}{l}-0.0039 \\
(1.5517)\end{array}$ & $\begin{array}{l}-0.0035 \\
(1.5178)\end{array}$ & $\begin{array}{l}-0.0031 \\
(1.6046)\end{array}$ & $\begin{array}{l}-0.0030 \\
(1.6626)^{*}\end{array}$ & $\begin{array}{l}-0.0029 \\
(1.6680)^{*}\end{array}$ & $\begin{array}{l}-0.0033 \\
(1.9792)^{*}\end{array}$ & $\begin{array}{l}-0.0036 \\
(2.2647) * *\end{array}$ & $\begin{array}{l}-0.0039 \\
(2.4030) * *\end{array}$ & $\begin{array}{l}-0.0040 \\
(2.5902) * *\end{array}$ \\
\hline
\end{tabular}

T-statistics in brackets. ${ }^{* *}$ significant at the $1 \%$ significance level. 
Table 5: Average Monthly Return From 2003 to 2013 in South Africa (one month lag)

Table 5 reports the results of the average monthly returns for 60 momentum strategies from January 2003 to December 2013 in Johannesburg Stock Exchange. Each stock which is ranked and arranged into 10 equal deciles in the light of the past 1, 3, 6, 9 and 12 months and is simultaneously held for $1-12$ months. For each of the 60 strategies, the average monthly returns for winner portfolio, deciles 2 to 9 portfolios, loser portfolio and winner-loser portfolio, and the t-statistic for the winner-loser portfolio are presented.

\begin{tabular}{|c|c|c|c|c|c|c|c|c|c|c|c|c|c|}
\hline \multirow{2}{*}{$\begin{array}{l}\text { Formation } \\
\text { Period } \\
\text { (month) }\end{array}$} & \multirow[t]{2}{*}{ Portfolio } & \multicolumn{12}{|c|}{ Holding Period (Month) } \\
\hline & & 1 & 2 & 3 & 4 & 5 & 6 & 7 & 8 & 9 & 10 & 11 & 12 \\
\hline \multirow[t]{3}{*}{1} & Loser & 0.0070 & -0.0041 & -0.0030 & -0.0001 & 0.0052 & 0.0053 & 0.0052 & 0.0050 & 0.0060 & 0.0063 & 0.0068 & 0.0071 \\
\hline & Winner & 0.0373 & -0.0036 & -0.0026 & -0.0020 & -0.0019 & -0.0019 & -0.0011 & -0.0030 & -0.0040 & -0.0047 & -0.0055 & -0.0061 \\
\hline & $\begin{array}{l}\text { Winner- } \\
\text { Loser }\end{array}$ & $\begin{array}{l}0.0303 \\
(3.2241)^{*} \\
* *\end{array}$ & $\begin{array}{l}0.0005 \\
(3.7839 \\
)_{* * *}\end{array}$ & $\begin{array}{l}0.0004 \\
(2.5247)^{* *}\end{array}$ & $\begin{array}{l}-0.0019 \\
(2.3951)^{*} \\
*\end{array}$ & $\begin{array}{l}-0.0071 \\
(2.5373)^{* *}\end{array}$ & $\begin{array}{l}-0.0072 \\
(1.1197)\end{array}$ & $\begin{array}{l}-0.0063 \\
(3.8469)^{* *} \\
*\end{array}$ & $\begin{array}{l}-0.0080 \\
(2.5714)^{* *}\end{array}$ & $\begin{array}{l}-0.0100 \\
(1.3050)\end{array}$ & $\begin{array}{l}-0.0110 \\
(1.0559)\end{array}$ & $\begin{array}{l}-0.0123 \\
(0.2764)\end{array}$ & $\begin{array}{l}-0.0132 \\
(1.6060)\end{array}$ \\
\hline \multirow[t]{3}{*}{3} & Loser & 0.0071 & -0.0038 & -0.0039 & -0.0009 & 0.0061 & 0.0060 & 0.0050 & 0.0073 & 0.0066 & 0.0044 & 0.0074 & 0.0081 \\
\hline & Winner & 0.0098 & -0.0051 & -0.0044 & -0.0040 & -0.0038 & -0.0040 & -0.0040 & -0.0053 & -0.0059 & -0.0062 & -0.0071 & -0.0088 \\
\hline & $\begin{array}{l}\text { Winner- } \\
\text { Loser }\end{array}$ & $\begin{array}{l}0.0027 \\
(0.0896)\end{array}$ & $\begin{array}{l}-0.0013 \\
(1.2326 \\
)\end{array}$ & $\begin{array}{l}-0.0005 \\
(0.0438)\end{array}$ & $\begin{array}{l}-0.0031 \\
(1.9186)^{*}\end{array}$ & $\begin{array}{l}-0.0099 \\
(2.8919)^{* * *} \\
*\end{array}$ & $\begin{array}{l}-0.0100 \\
(0.1654)\end{array}$ & $\begin{array}{l}-0.0090 \\
(2.8141)^{* * *} \\
*\end{array}$ & $\begin{array}{l}-0.0126 \\
(2.3216)^{* *}\end{array}$ & $\begin{array}{l}-0.0125 \\
(0.2301)\end{array}$ & $\begin{array}{l}-0.0106 \\
(2.2651)^{*} \\
*\end{array}$ & $\begin{array}{l}-0.0145 \\
(2.0308) * *\end{array}$ & $\begin{array}{l}-0.0169 \\
(2.3040)^{* *}\end{array}$ \\
\hline \multirow[t]{3}{*}{6} & Loser & 0.0081 & -0.0051 & -0.0037 & -0.0011 & 0.0055 & 0.0061 & 0.0051 & 0.0074 & 0.0068 & 0.0045 & 0.0076 & 0.0083 \\
\hline & Winner & 0.0088 & -0.0055 & -0.0055 & -0.0054 & -0.0052 & -0.0049 & -0.0047 & -0.0060 & -0.0070 & -0.0074 & -0.0083 & -0.0093 \\
\hline & $\begin{array}{l}\text { Winner- } \\
\text { Loser }\end{array}$ & $\begin{array}{l}0.0007 \\
(2.5304)^{*} \\
*\end{array}$ & $\begin{array}{l}-0.0004 \\
(2.1452 \\
)^{* *}\end{array}$ & $\begin{array}{l}-0.0018 \\
(1.7434)^{*}\end{array}$ & $\begin{array}{l}-0.0043 \\
(2.1413)^{*} \\
*\end{array}$ & $\begin{array}{l}-0.0107 \\
(1.9293)^{*}\end{array}$ & $\begin{array}{l}-0.0110 \\
(0.1348)\end{array}$ & $\begin{array}{l}-0.0098 \\
(0.4687)\end{array}$ & $\begin{array}{l}-0.0134 \\
(1.349)\end{array}$ & $\begin{array}{l}-0.0138 \\
(0.7937)\end{array}$ & $\begin{array}{l}-0.0119 \\
(2.1652)^{*} \\
*\end{array}$ & $\begin{array}{l}-0.0159 \\
(1.6632)^{*}\end{array}$ & $\begin{array}{l}-0.0176 \\
(2.9050)^{* *} \\
*\end{array}$ \\
\hline \multirow[t]{3}{*}{9} & Loser & 0.0088 & -0.0030 & -0.0026 & 0.0005 & 0.0059 & 0.0062 & 0.0054 & 0.0043 & 0.0068 & 0.0049 & 0.0074 & 0.0081 \\
\hline & Winner & 0.0383 & -0.0027 & -0.0020 & -0.0017 & -0.0016 & -0.0013 & -0.0003 & -0.0022 & -0.0037 & -0.0050 & -0.0057 & -0.0058 \\
\hline & $\begin{array}{l}\text { Winner- } \\
\text { Loser }\end{array}$ & $\begin{array}{l}0.0295 \\
(2.6139)^{*} \\
* *\end{array}$ & $\begin{array}{l}0.0003 \\
(2.1251 \\
)^{* *}\end{array}$ & $\begin{array}{l}0.0006 \\
(2.7373) * * \\
*\end{array}$ & $\begin{array}{l}-0.0022 \\
(0.5252)\end{array}$ & $\begin{array}{l}-0.0075 \\
(1.8491)^{*}\end{array}$ & $\begin{array}{l}-0.0075 \\
(2.6235)^{* *} \\
*\end{array}$ & $\begin{array}{l}-0.0057 \\
(2.1473)^{* *}\end{array}$ & $\begin{array}{l}-0.0065 \\
(2.9038) * * \\
*\end{array}$ & $\begin{array}{l}-0.0105 \\
(2.5033)^{*} \\
*\end{array}$ & $\begin{array}{l}-0.0099 \\
(2.2355) * \\
*\end{array}$ & $\begin{array}{l}-0.0131 \\
(1.0675)\end{array}$ & $\begin{array}{l}-0.0139 \\
(2.1052) * *\end{array}$ \\
\hline \multirow[t]{3}{*}{12} & Loser & 0.0084 & -0.0037 & -0.0027 & 0.0004 & 0.0061 & 0.0056 & 0.0066 & 0.0068 & 0.0069 & 0.0074 & 0.0079 & 0.0089 \\
\hline & Winner & 0.0399 & -0.0011 & -0.0018 & -0.0017 & -0.0019 & -0.0016 & -0.0010 & -0.0029 & -0.0029 & -0.0039 & -0.0041 & -0.0060 \\
\hline & $\begin{array}{l}\text { Winner- } \\
\text { Loser }\end{array}$ & $\begin{array}{l}0.0315 \\
(0.4639)\end{array}$ & $\begin{array}{l}0.0026 \\
(1.9257 \\
)^{*}\end{array}$ & $\begin{array}{l}0.0009 \\
(1.9746)^{* *}\end{array}$ & $\begin{array}{l}-0.0021 \\
(0.2454)\end{array}$ & $\begin{array}{l}-0.0080 \\
(0.9596)\end{array}$ & $\begin{array}{l}-0.0072 \\
(1.8533)^{*}\end{array}$ & $\begin{array}{l}-0.0076 \\
(2.5491)^{* *}\end{array}$ & $\begin{array}{l}-0.0097 \\
(2.6648) * * \\
*\end{array}$ & $\begin{array}{l}-0.0098 \\
(1.6057)\end{array}$ & $\begin{array}{l}-0.0113 \\
(2.5266)^{*} \\
*\end{array}$ & $\begin{array}{l}-0.0120 \\
(2.7373)^{* *} \\
*\end{array}$ & $\begin{array}{l}-0.0149 \\
(2.4166) * *\end{array}$ \\
\hline
\end{tabular}

T-statistics in brackets . ${ }^{* *}$ significant at the $1 \%$ significance level. 


\section{Performance of loser portfolio in Brazil}

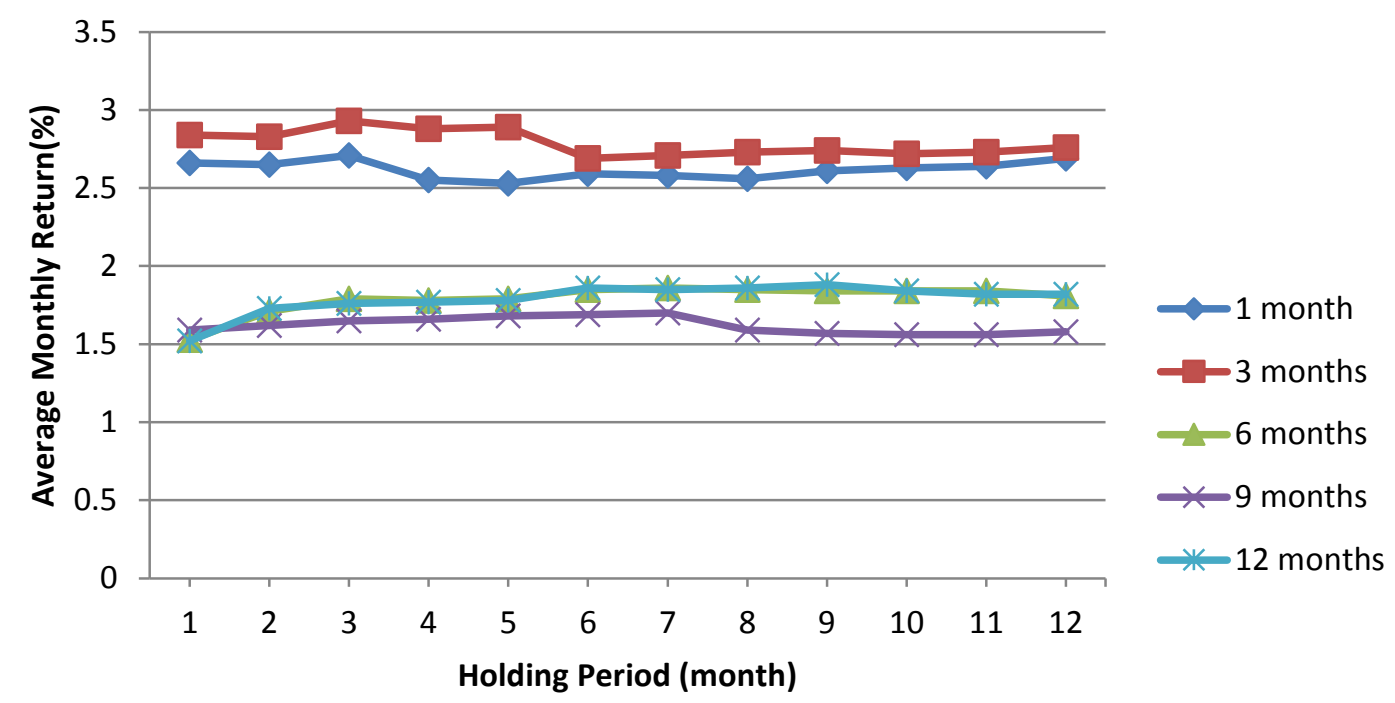

Figure 1. Buy-and-hold average monthly loser returns to various momentum strategies. This graph depicts buy-and-hold average monthly loser returns to five price momentum strategies. Each month, stocks are independently sorted into 10 price momentum portfolios which are formed in the past 1,3, 6, 9 and 12 months.

\section{Performance of winner portfolio in Brazil}

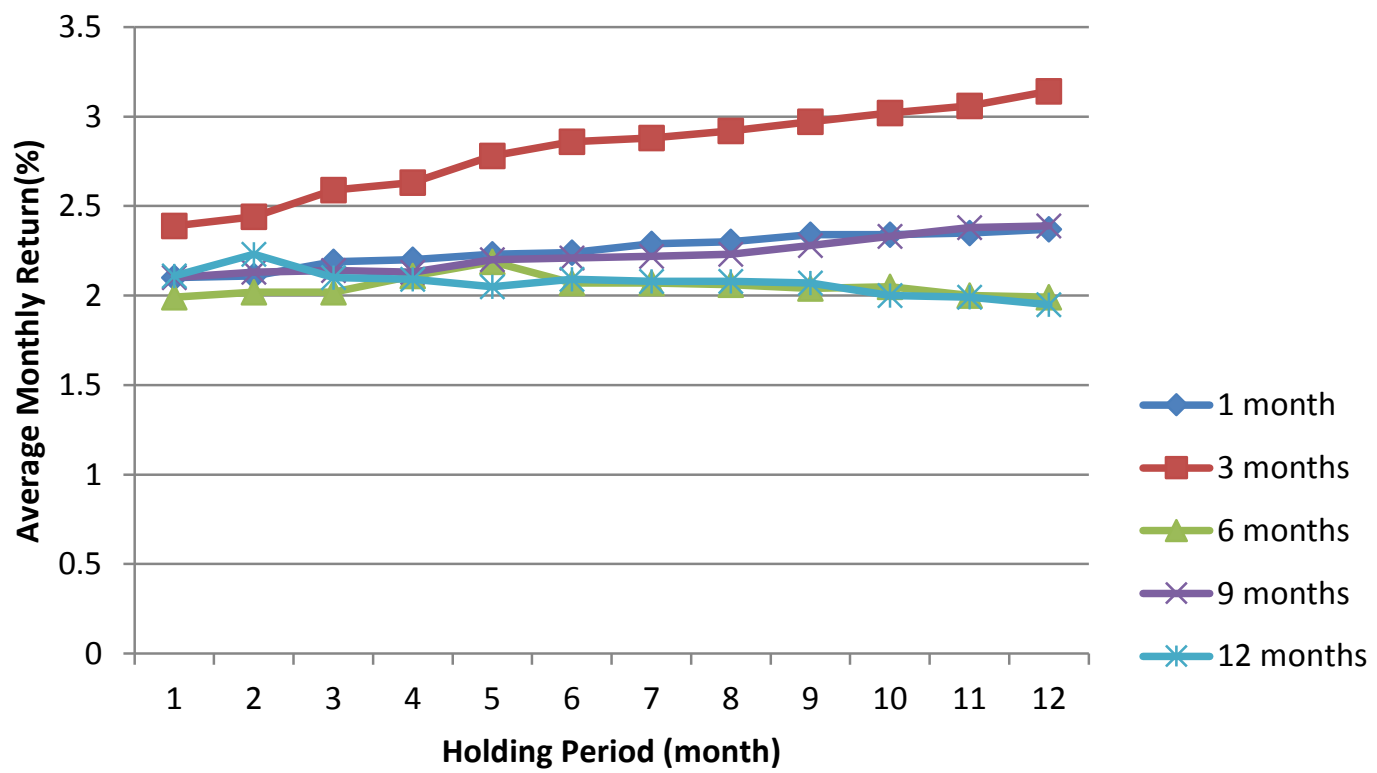

Figure 2. Buy-and-hold average monthly winner returns to various momentum strategies. This graph depicts buy-and-hold average monthly winner returns to five price momentum strategies. Each month, stocks are independently sorted into 10 price momentum portfolios which are formed in the past 1,3, 6, 9 and 12 months. 


\section{Performance of Momentum Portfolio in Brazil}

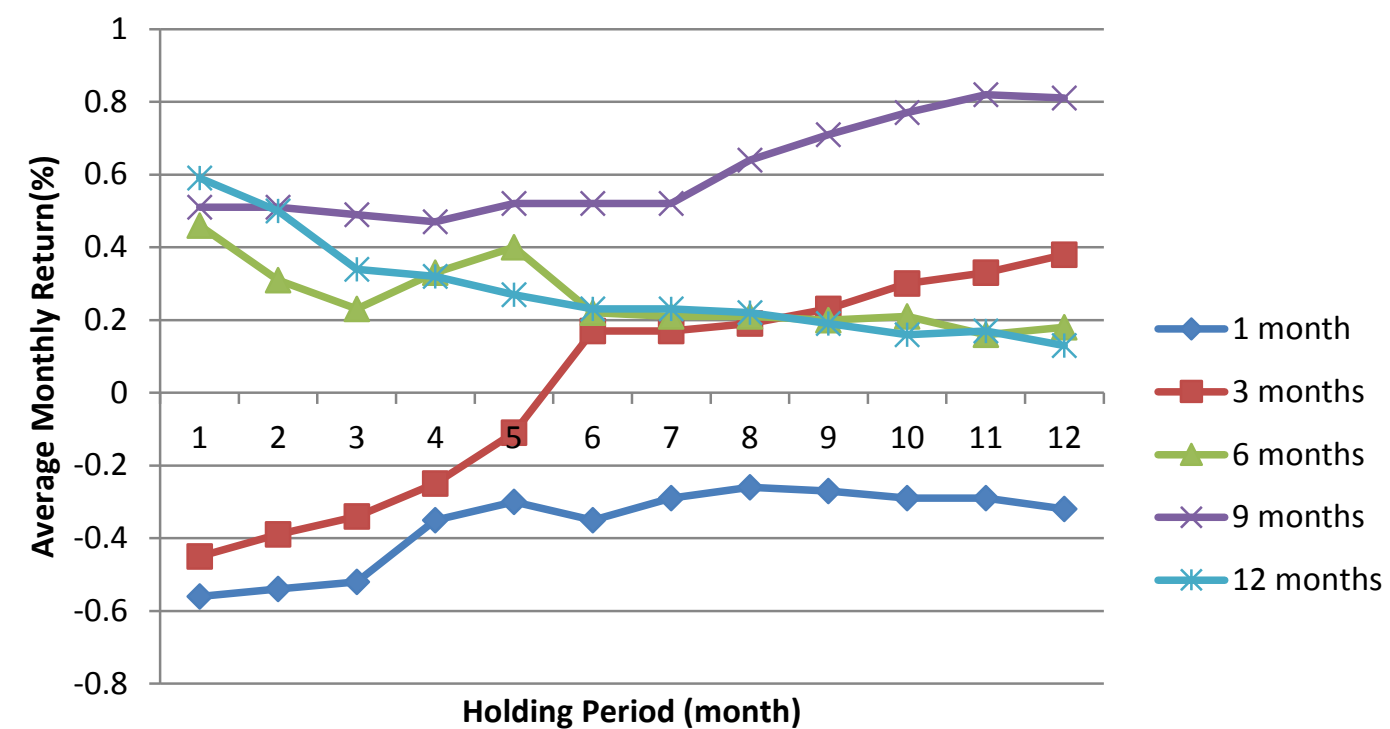

Figure 3. Buy-and-hold average monthly momentum returns to various momentum strategies. This graph depicts buy-and-hold average monthly momentum returns to five price momentum strategies. Each month, stocks are independently sorted into 10 price momentum portfolios which are formed in the past 1, 3, 6, 9 and 12 months.

Performance of loser portfolios in Russia

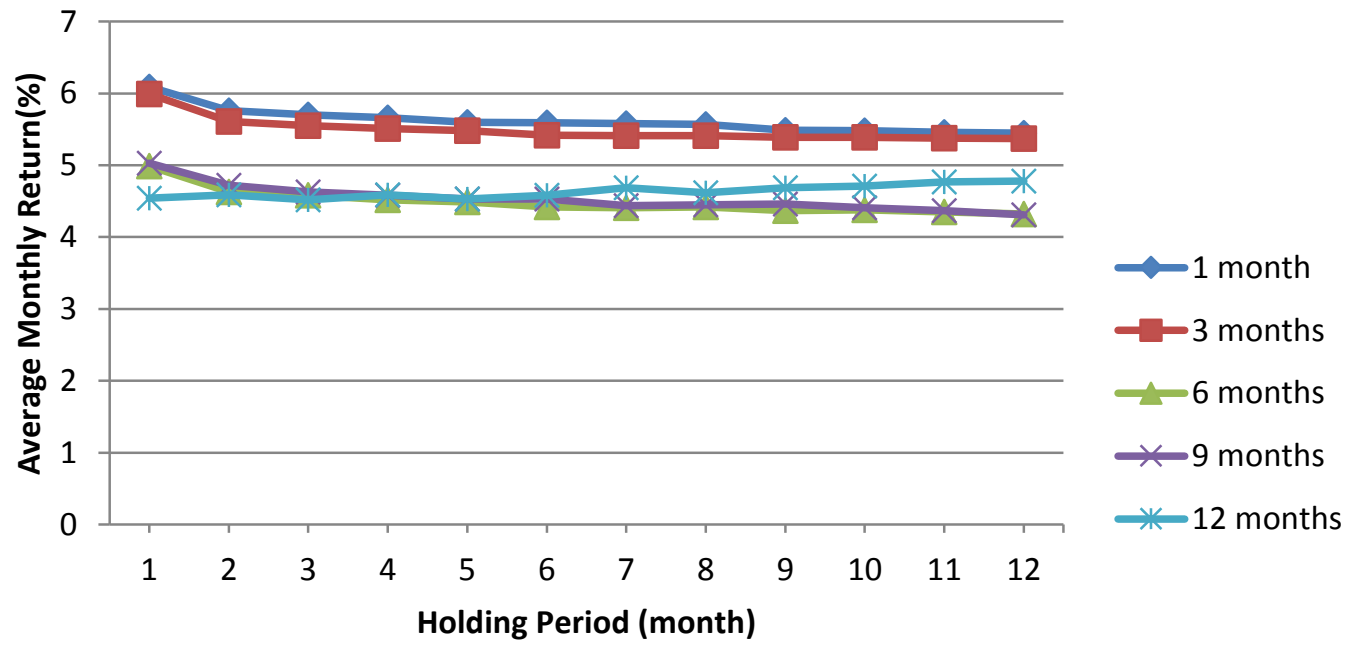

Figure 4. Buy-and-hold average monthly loser returns to various momentum strategies. This graph depicts buy-and-hold average monthly loser returns to five price momentum strategies. Each month, stocks are independently sorted into 10 price 


\section{Performance of winner portfolio in Russia}

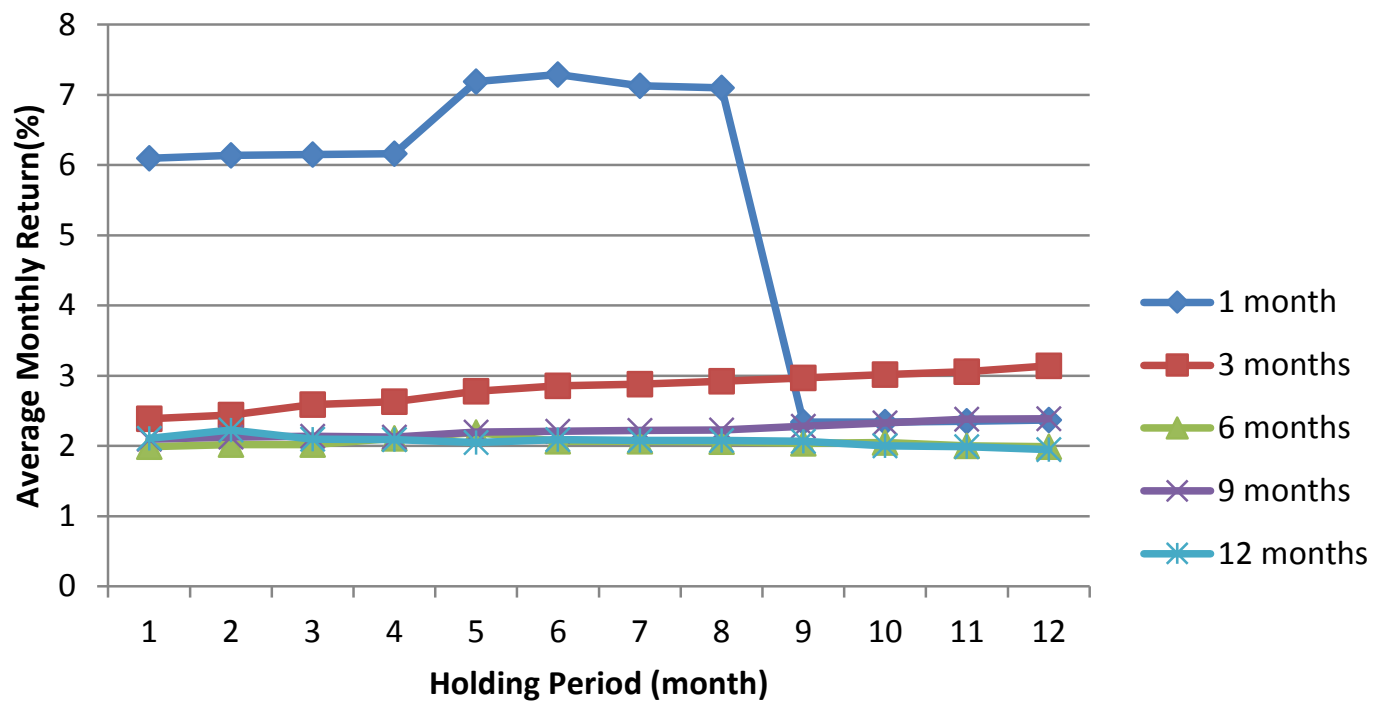

Figure 5. Buy-and-hold average monthly winner returns to various momentum strategies. This graph depicts buy-and-hold average monthly winner returns to five price momentum strategies. Each month, stocks are independently sorted into 10 price momentum portfolios which are formed in the past 1,3, 6, 9 and 12 months.

\section{Performance of Momentum Portfolio in Russia}

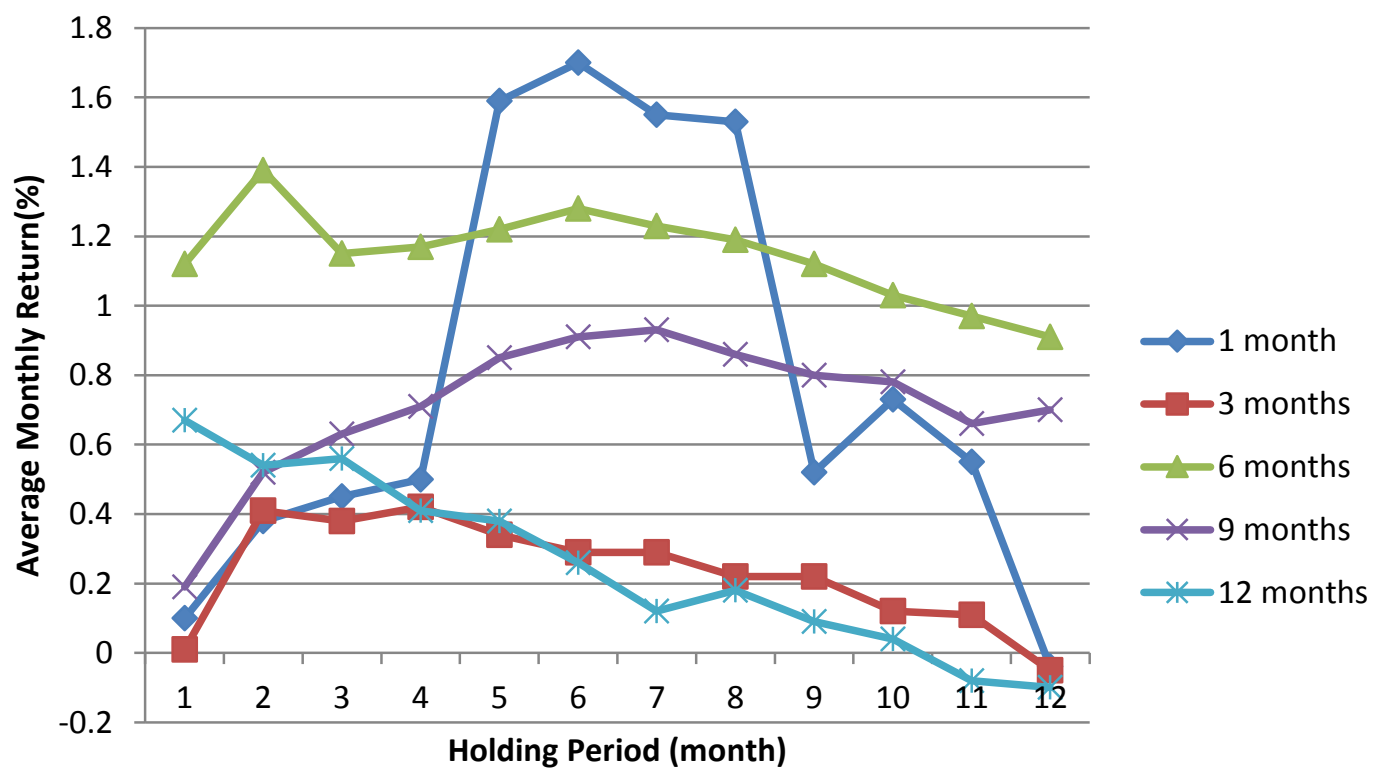

Figure 6. Buy-and-hold average monthly momentum returns to various momentum strategies. This graph depicts buy-and-hold average monthly momentum returns to five price momentum strategies. Each month, stocks are independently sorted into 10 price momentum portfolios which are formed in the past 1, 3, 6, 9 and 12 months. 

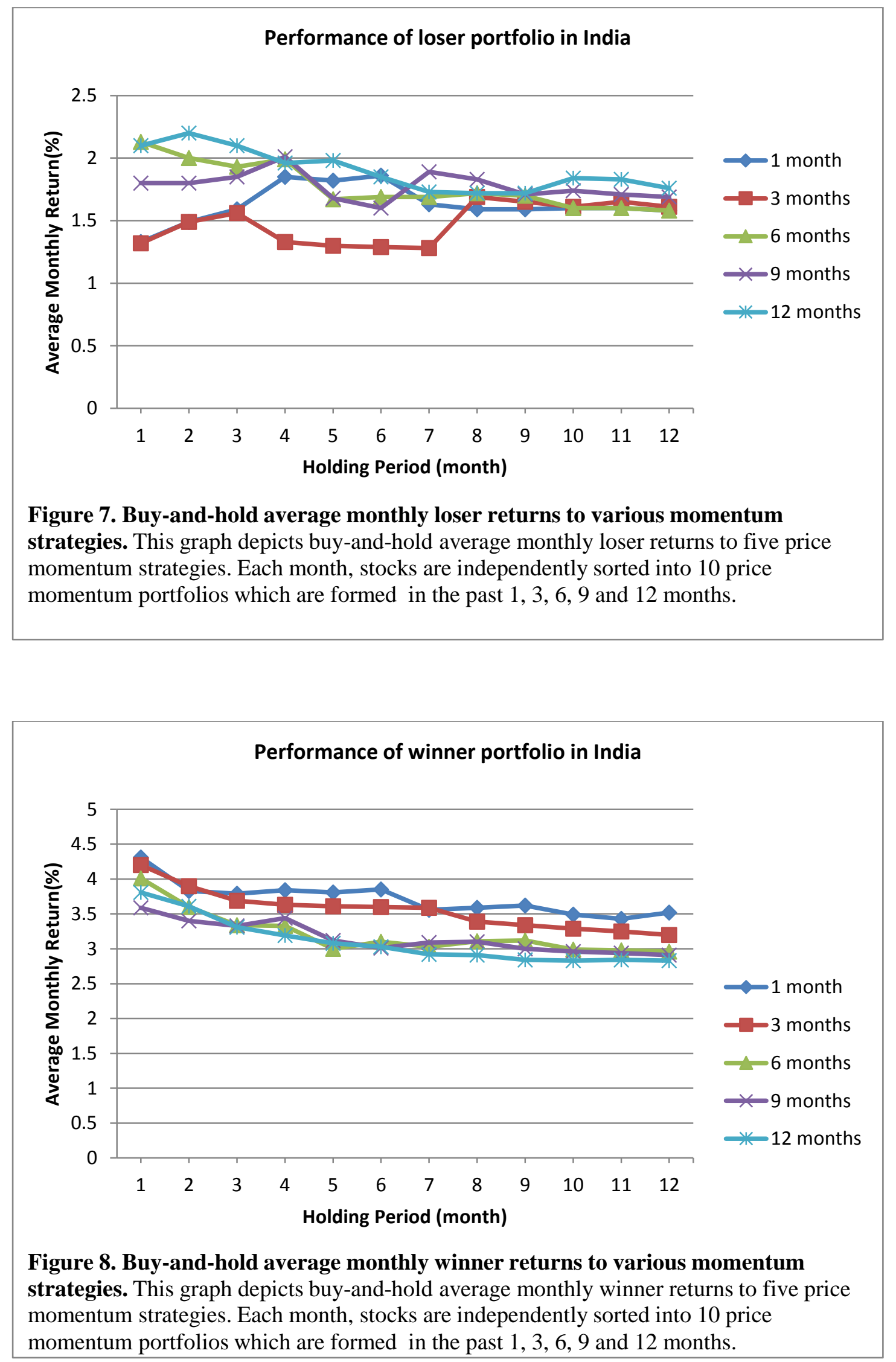


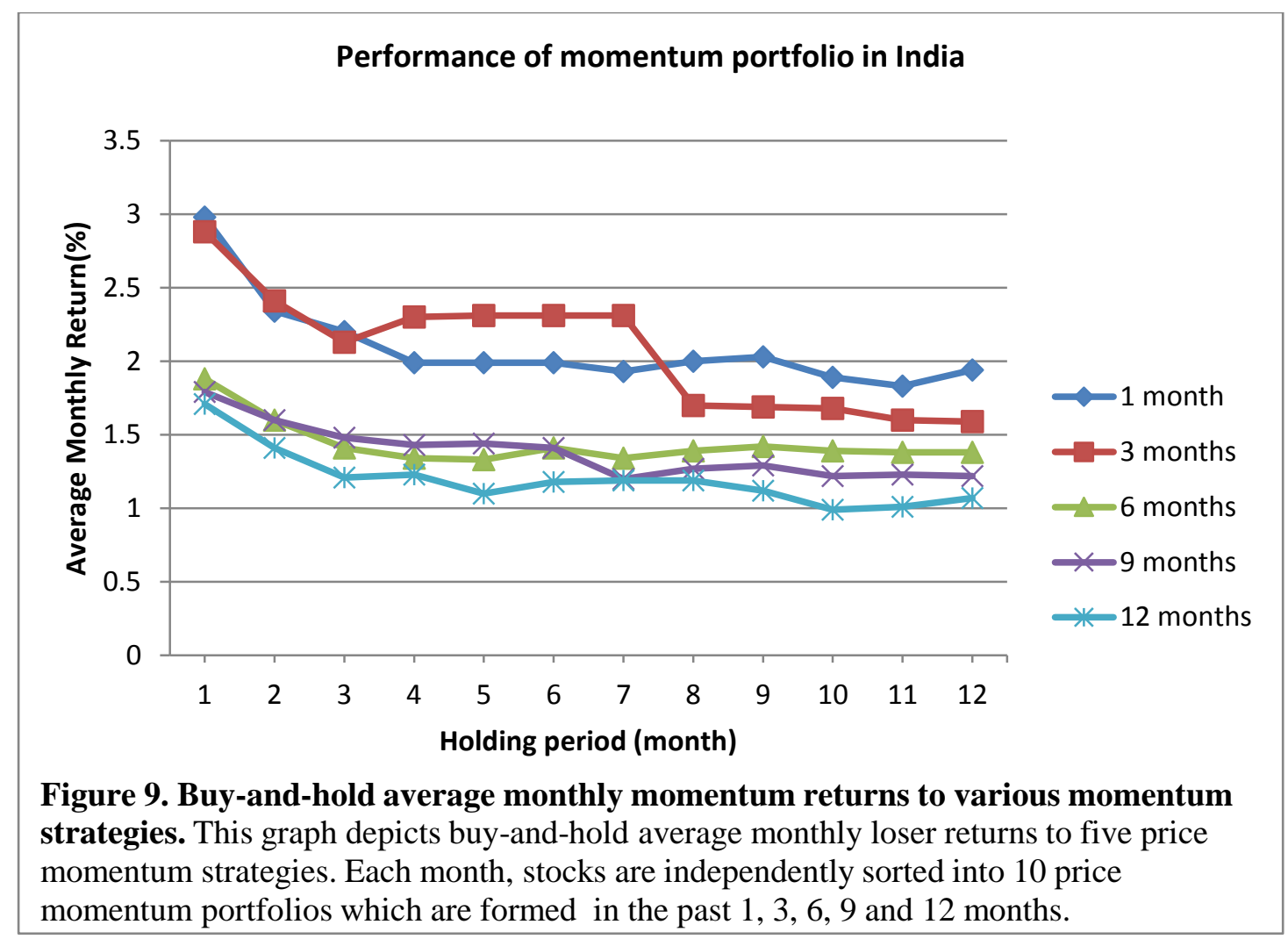

Performance of loser portfolio in China

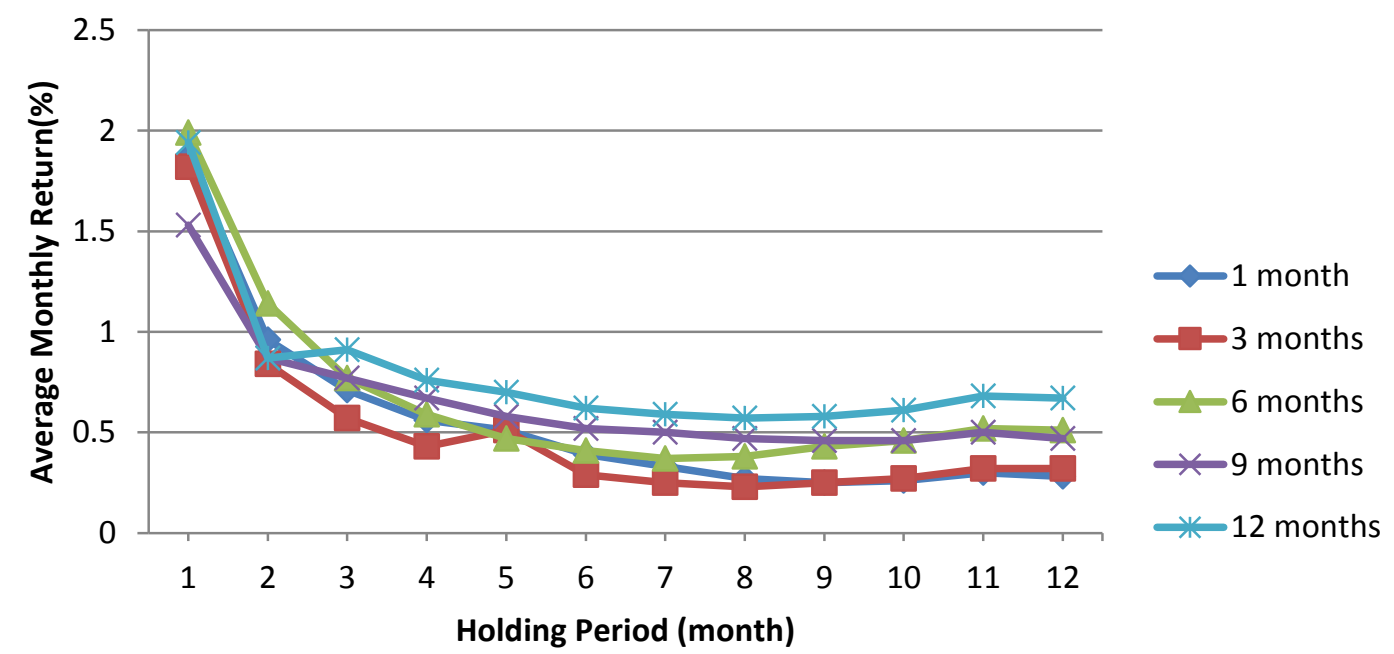

Figure 10. Buy-and-hold average monthly loser returns to various momentum strategies. This graph depicts buy-and-hold average monthly loser returns to five price momentum strategies. Each month, stocks are independently sorted into 10 price 


\section{Performance of winner portfolio in China}

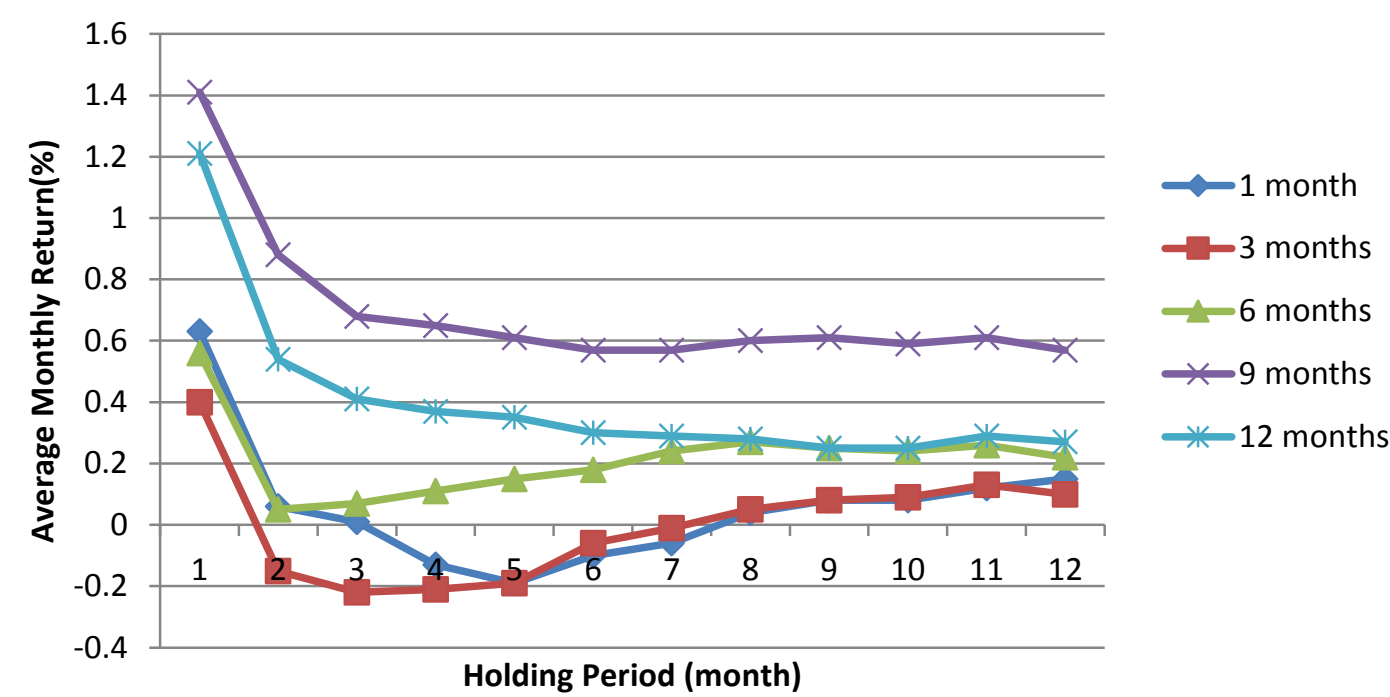

Figure 11. Buy-and-hold average monthly winner returns to various momentum strategies. This graph depicts buy-and-hold average monthly winner returns to five price momentum strategies. Each month, stocks are independently sorted into 10 price momentum portfolios which are formed in the past 1,3, 6, 9 and 12 months.

\section{Performance of Momentum Portfolio in China}

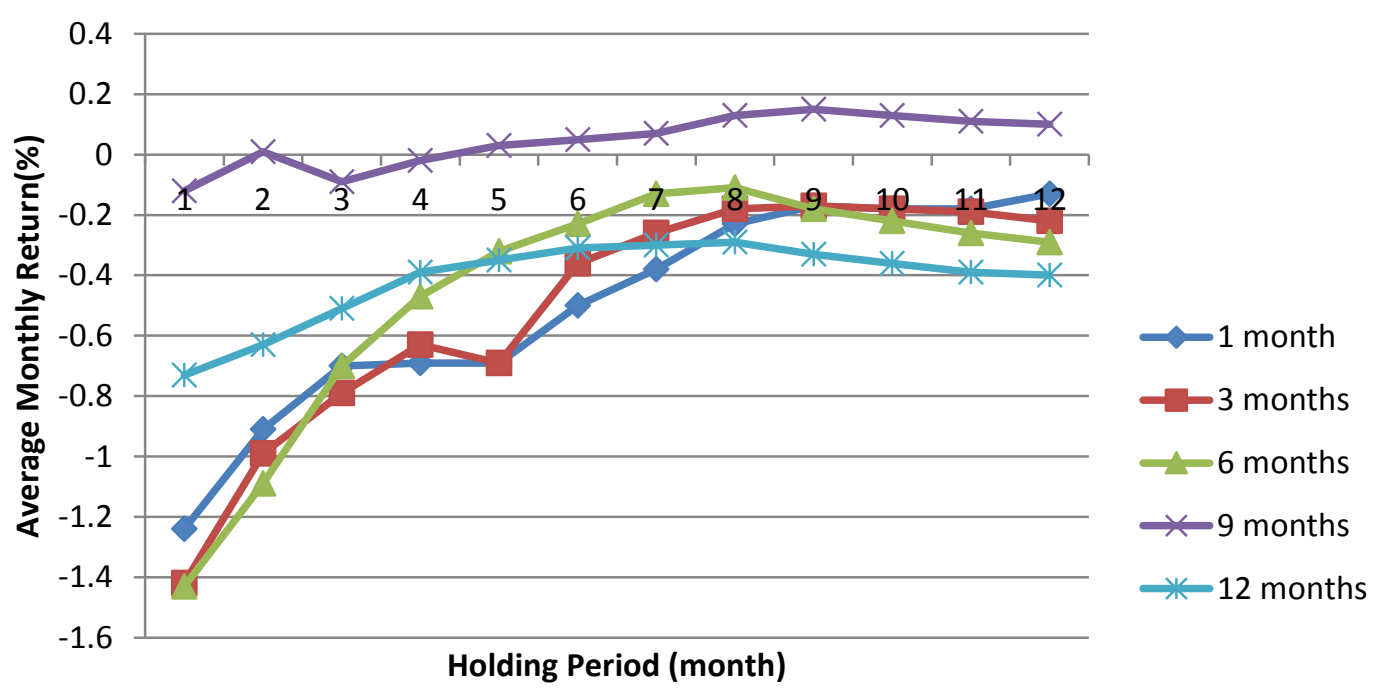

Figure 12. Buy-and-hold average monthly momentum returns to various momentum strategies. This graph depicts buy-and-hold average monthly momentum returns to five price momentum strategies. Each month, stocks are independently sorted into 10 price momentum portfolios which are formed in the past 1,3, 6, 9 and 12 months. 

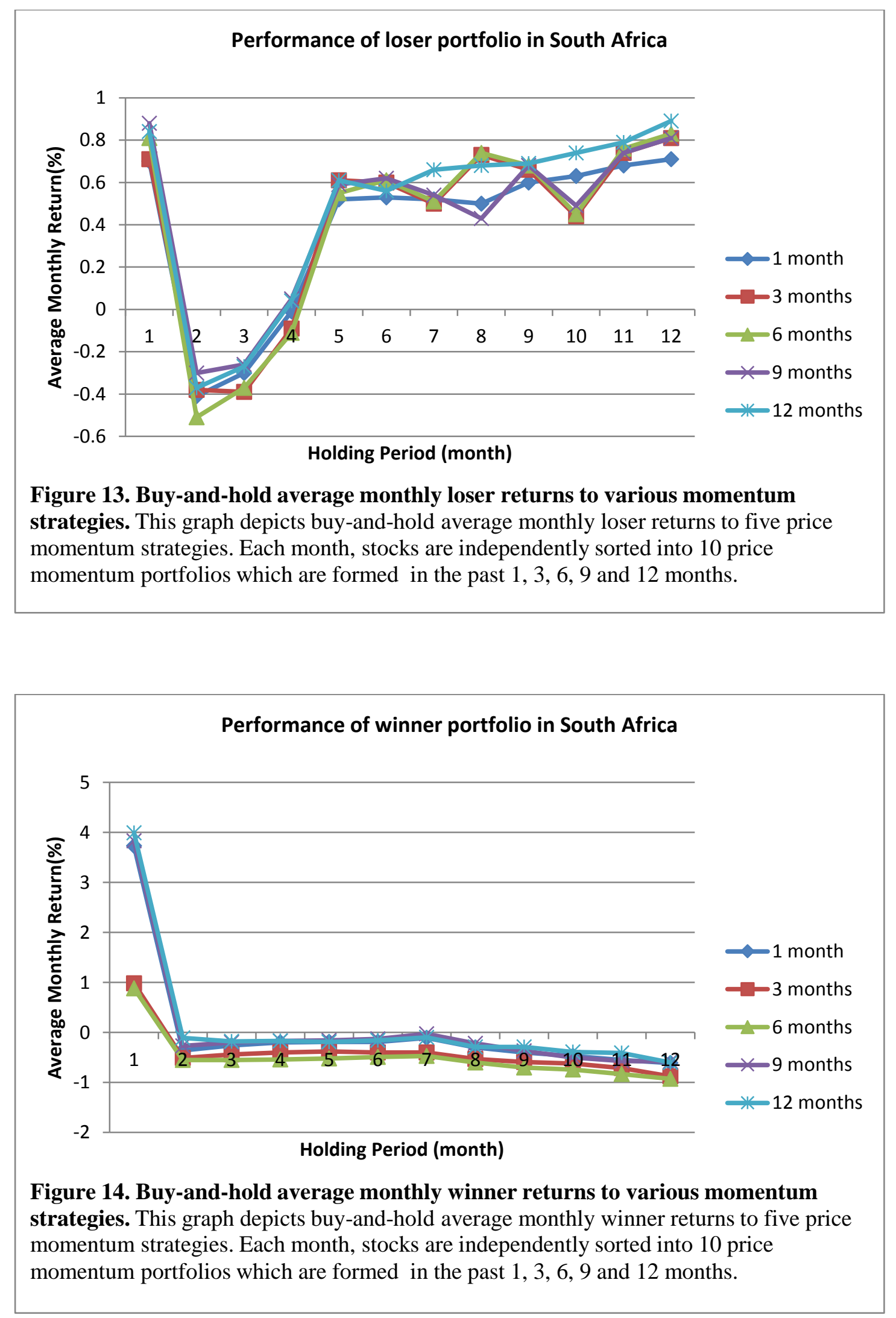


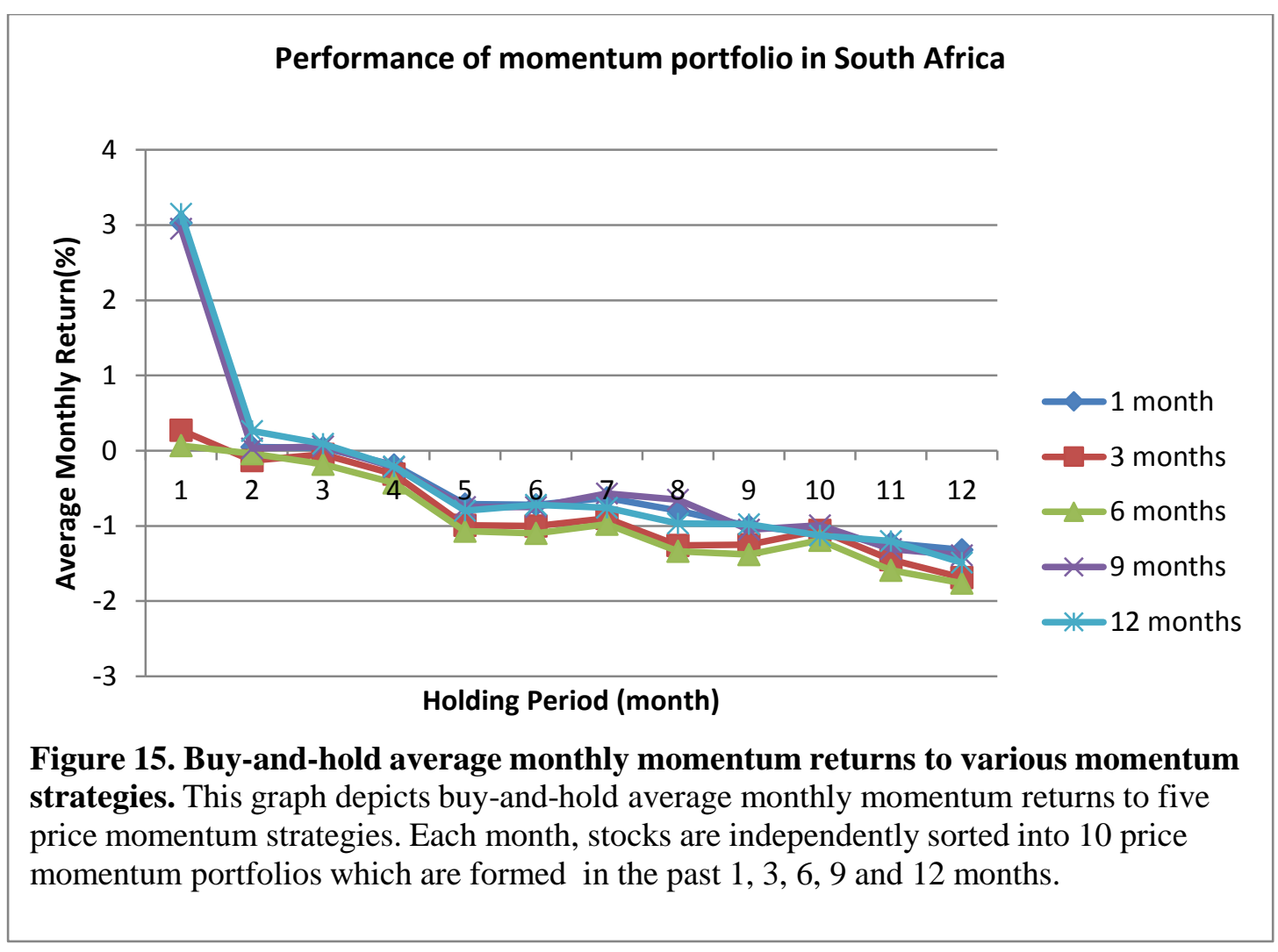

